\title{
Are Lawyers Worth the Cost? \\ Legal Counsel in Environmental Criminal Court Cases
}

\author{
Dietrich Earnhart \\ Department of Economics \\ University of Kansas \\ Sandra Rousseau \\ Faculty of Economics and Business \\ KU Leuven
}

August 20, 2019

Published as: Earnhart, D. and S. Rousseau (2019). Are lawyers worth the cost? Legal counsel in environmental criminal court cases. International Review of Law and Economics, vol.60, nr. 105857 (doi : 10.1016/j.irle.2019.105857)

\begin{abstract}
Lawyers arguably play a critical role in court proceedings. However, lawyers are expensive to hire. Defendants prosecuted by courts surely hope that legal representation by lawyer is worth the expense. This study empirically explores this trade-off by estimating the effect of legal representation on various court decisions surrounding the prosecution of individuals in environmental criminal cases in Flanders (Belgium) between 2003 and 2006. Our results apparently reveal that the presence of a lawyer meaningfully lowers the likelihoods of courts convicting a defendant and imposing monetary sanctions and prison sentences on defendants and reduces the magnitudes of monetary sanctions and prison terms. However, these benefits may not outweigh the costs of hiring a lawyer. Consequently, our results do not unequivocally demonstrate the prudence of securing legal presentation in court. Instead, conclusions depend on the benefits associated with reduced prison terms and the expected number of hours billed by the hired lawyer.
\end{abstract}

Keywords: lawyer; legal representation; environmental crime; sanctions; incarceration

Contact Information: Sandra Rousseau, CEDON, Faculty of Business and Economics, KU Leuven, Warmoesberg 26, B-1000 Brussel, Belgium, sandra.rousseau@kuleuven.be

Acknowledgements: We thank Carole M. Billiet and David Slusky for their useful comments on a previous version of this manuscript. 


\section{Introduction}

Yearly, millions of people must appear before a variety of courts. For instance, 1.62 million defendants were prosecuted in criminal cases in the UK magistrates' courts in 2011 (Ministry of Justice, 2012). Given the serious consequences of prosecution, it seems prudent to secure a lawyer since lawyers (should) have superior knowledge of legal text and experience with court proceedings. However, courts generally do not provide lawyers; worse yet, lawyers are expensive to hire. Given this expense, we can wonder whether lawyers are worth their price by helping to shape the outcomes of court trials.

The vast majority of past empirical research studying the effect of legal representation on case outcomes focuses on common law countries, with the largest proportion using US data [see Sandefur (2010) and Greiner and Pattanayak (2012) for overviews] and only a limited fraction using UK data (e.g., Genn and Genn, 1989; Latreille et al., 2005; Pleasence and Balmer, 2007). Studies set in a civil law country are extremely scarce, with the notable exceptional studies of Vietnam (Huang, 2008; Huang et al., 2014) and Slovenia (Grajzl et al., 2016). Furthermore, these previous studies cover a wide variety of courts and proceedings, such as juvenile courts (Clarke and Koch, 1980; Feld, 1989), tax courts (Lederman and Hrung, 2006), administrative tribunals (Genn and Genn, 1989; Monsma and Lempert, 1992), housing courts (Seron et al., 2001), constitutional civil rights cases (Schwab and Eisenberg, 1988), civil cases (Huang, 2008) and bail hearings (Colbert et al., 2002). However, to our best knowledge, no previous study analyzes environmental cases. Of the existing studies, most focus on the value of representation in the context of civil and administrative procedures. Surprisingly few studies examine the value of representation in the context of criminal litigation procedures. Overall, research on the value of legal representation is limited. As noted by Monsma and Lempert (1992), the limited number of studies probably stems from researchers' focus on legal contexts in which legal representation is either so common that defendants must actively work to not use a lawyer or so unusual that it cannot serve as 
an explanatory factor because no variation exists (Huang, 2008). For example, we cannot consider environmental cases in the US since all defendants hire lawyers.

Our empirical study contributes to this literature in four important ways. As the first contribution, we explore a new type of criminal setting: regulatory law. Previous studies focus on standard crimes, such as burglary, arson, assaults. Our exploration is useful since results based on other criminal settings most likely do not generalize to the regulatory setting. Second, we explore the extensive margin by distinguishing between the presence and absence of counsel in a criminal setting. Prior studies of criminal cases distinguish only between public counsel and private counsel (Clarke and Koch, 1980; Anderson and Heaton, 2012), yet previous studies of the extensive margin focus exclusively on noncriminal proceedings, e.g., divorce, child custody (Greiner and Pattanayak, 2012). Third, we explore the effect of legal representation in a civil law system. Common law and civil law systems differ greatly (Cooter and Ulen, 2013). Thus, the role of lawyers differs substantially. For instance, common law systems depend on precedents; therefore, lawyers can help defendants by finding and citing relevant and helpful previous cases. In contrast, civil law systems do not depend on precedents; consequently, lawyers do not need to identify such cases. Fourth, we compare the benefits and costs of legal representation using a simple design, which still represents a contribution since few studies even attempt a comparison.

To generate these contributions, we examine the benefits and costs of legal representation within a civil law context for criminal procedures on the previously ignored topic of environmental crime. Specifically, we explore the prosecution of environmental criminal offenses committed by individuals in Belgium, in particular, in the region of Flanders. Interestingly, this setting represents a legal context where a sizable portion of defendants do not hire a lawyer since they are not legally required to do so. Of the prosecuted individuals in our sample, some $40 \%$ chose not to be represented by a lawyer. ${ }^{1}$ As our

\footnotetext{
${ }^{1}$ We purposively do not explore cases involving legal entities, e.g., companies, since these defendants nearly always hire legal representation.
} 
identification strategy, we distinguish between cases with legal representation and cases without representation. As our strategy does not exploit any random assignment of legal counsel or natural experiment, we rely on exogenous variation in legal representation. Of course, the presence of a legal counsel may be endogenously determined, which would bias our estimate either through the selection process of defendants hiring a lawyer or that of lawyers accepting a client; we assess the implications of this possible, if not likely, bias in sub-section 6.4. Given this bias, our estimates may not reflect causal effects.

Our empirical results reveal that the hiring of a lawyer lowers the likelihoods of being found guilty, receiving a fine and monetary sanctions in general, and incarceration. Beyond the likelihood of receiving particular sanctions, the presence of a lawyer also lowers the magnitude of fines and monetary sanctions in general as well as the length of prison terms. However, some portions of sanctions are typically suspended, the remaining portions deemed the effective magnitudes. Given this distinction, we find that hiring a lawyer tends to raise the suspended fine magnitude and, not surprisingly, lower the effective fine magnitude. On the other hand, the hiring of a lawyer lowers the effective prison term, yet does not seem to influence the suspended prison term. Lastly, we compare these benefits of legal representation with the likely costs of representation.

In the following section, we review the relevant literature and highlight the contribution of the current study. Section 3 presents the legal context of the Flanders, while Section 4 describes the dataset. Section 5 presents the econometric framework. Section 6 discusses the estimation results and investigates the trade-off between the benefits and costs of hiring a lawyer using a simple back-of-the-envelope calculation. Section 7 explores the role of Flemish legal counsel in practice. Section 8 concludes.

\section{Literature Review and Contribution of Present Study}

The current study relates to two strands of the literature: (1) research identifying the role and 
value of legal representation in legal proceedings and (2) research exploring the determinants of environmental sanctions.

As mentioned above, the relevant empirical literature studies the role of lawyers in legal proceedings in several different settings. Previous studies examine the impact of legal representation for a variety of procedural steps, a variety of offenses, and a variety of geographical settings. Most of these empirical studies focus on the United States, although some studies examine other countries.

Most relevant to our exploration, previous studies explore the impact of legal representation on case outcomes. The empirical evidence of this impact, based on the comparison between cases with and without representation, is ambiguous. By examining two North Carolina juvenile courts, Clarke and Koch (1980, p. 263) conclude 'that the participation of lawyers in juvenile court was largely a formality, a token compliance with due process requirements rather than an integral part of court fact-finding'. On the other hand, Schwab and Eisenberg (1988) find that representation by counsel significantly correlates with success of constitutional civil rights cases in U.S. federal courts. By assessing the public housing eviction process in Hawaii (US) from 1966 to 1985, Monsma and Lempert (1992) find that the likelihood that legal representation aids a tenant depends on case type and varies over time. By exploring the New York City's Housing Court, Seron et al. (2012) find that low income tenants with legal representation enjoy significantly more beneficial outcomes than their counterparts without legal representation, independent of the merits of the case. Huang (2008) studies more than 100,000 civil cases terminated in Taiwan from 2000 to 2006 . This study shows that parties were less likely to settle a case when both were represented, while parties were most likely to settle a case when neither was represented. This study also shows that legal representation had no significant bearing on the case outcomes when the parties went to trial. ${ }^{2}$

\footnotetext{
${ }^{2}$ As a related study, Abrams and Yoon (2007) exploit the random assignment of public defenders in Clark County of Nevada to investigate attorney ability.
} 
Some studies explore other procedural steps. For example, Colbert et al. (2002) explore the impact of legal presentation in pretrial bail hearings in the US. The authors find that representation had a significant impact in bail hearings for non-violent offenses in Baltimore. The study shows that significantly more represented defendants were released from pretrial custody or had their bail reduced to an affordable amount than were unrepresented defendants. As another example, Ater et al. (2017) explore whether a reform to offer the right to publicly provided legal counsel in Israel affected arrest proceedings. Results reveal this reform reduced arrest duration and the likelihood of being charged.

Rather than exploring the influence of legal representation, some studies investigate the impact of different types of representation on case outcomes. For instance, Anderson and Heaton (2012) study the impact of public defenders versus appointed counsel in murder cases in Philadelphia (US). Compared to appointed counsel, public defenders in Philadelphia reduced their clients' murder conviction rate by $19 \%$ and lowered the probability that their clients received a life sentence by $62 \%$. Public defenders reduced overall time served in prison by $24 \%$. Previously, Clarke and Koch (1980) examine two North Carolina (US) juvenile courts in 1975-1976; they find that the type of counsel a child had (private, individually assigned, or specialized juvenile defender) made no difference in whether the child was deemed delinquent or was committed. Anderson et al. (2019) examine the effects of holistic defense offered to indigent clients, which helps to address underlying life complications, in contrast to traditional public defense. Results reveal that holistic defense does not appear to affect conviction rates, yet it reduces the likelihood of a custodial sentence and the expected sentence length. Greiner et al. (2013) use a randomized field experiment to compare a traditional attorney-client relationship and a limited legal assistance package in a legal setting where potential clients face eviction. Results show that the traditional relationship improved the likelihood of a client retaining his/her home.

To identify the benefits of legal representation, our empirical study examines environmental 
sanctioning decisions made by criminal courts in Belgium. In this way, our study contributes to the literature on the determinants of environmental sanctions (e.g., Deily and Gray, 1991; Oljaca et al., 1998; Deily and Gray, 2007). In particular, our study relates to studies that explore environmental sanctioning decisions made by Belgian legal authorities, including criminal courts, as well as public prosecutors and administrative authorities. Most of these Belgian studies exploit parts of the extensive Environmental LawForce dataset; these specific studies examine the use of non-monetary sanctions by lower criminal courts against corporate environmental offenders (Blondiau and Rousseau, 2010), the use of prison sentences by lower criminal courts against environmental offenders (Billiet and Rousseau, 2014), the use of harm-based versus act-based sanctions by lower criminal and administrative courts (Rousseau and Blondiau, 2014), the interactions between sanctioning decisions by lower criminal courts and the court of appeal (Billiet et al., 2014), and the comparison of the levels of administrative and criminal fines imposed by lower sanctioning authorities (Blondiau et al., 2015). One additional study - Faure and Svatikova (2012) - investigate the scope of criminal and administrative law enforcement of environmental violations in Belgium, along with three other West European jurisdictions.

In sum, our study contributes to the two identified literature strands in four ways: (1) explore a new type of criminal setting: regulatory law, (2) examine the extensive margin between the presence and absence of counsel in a criminal setting; (3) assess the effect of legal representation in a civil law system, and (4) compare the benefits and costs of legal representation. Our results appear to reveal that lawyers are at least effective at improving some legal outcomes but not effective at improving all legal outcomes. This said, since our analysis does not control for selection bias, our estimates may not reflect causal effects.

\section{Legal Context}

This section provides an overview of the characteristics of the Belgian criminal sanctioning 
system that are most relevant for the environmental cases in our dataset. For more details, see Billiet et al. (2014) and Billiet (2016). Belgian criminal court judges typically possess considerable discretion over their sanctioning decisions. Importantly, sentencing guidelines do not exist in Belgian criminal law. Criminal judges are not bound by the public prosecutors' sanctioning requests. Moreover, criminal judges are not constrained by the sanctions imposed in previous cases.

If facts and liability are proven and the defendant is not acquitted, which happens in nine out of ten cases (Billiet et al., 2009), the judges' first decision involves the choice between a postponement of a conviction and an actual conviction. Postponement of conviction basically represents a choice not to punish, even though the defendant is labelled as guilty, which includes a probationary period of one to five years in which the offender must not re-offend. When the criminal court opts to convict, its second decision concerns sanctions. The court needs to impose at least one principal sanction. Belgian criminal law offers three principal sanctions: imprisonment, fine, and community service (Van den Wyngaert, 2009). Each sanction is punitive in nature. The imposition of multiple principal sanctions is legally possible and quite common (Billiet and Rousseau, 2014). For each imposed principal sanction, the judge also needs to determine a sanction level that lies between the legal minima and maxima. The ranges between minimum and maximum levels are typically very large. The statutes reflected in our study provide for fines ranging from a minimum of $26 €$ to a maximum of $10,000,000 €$ and for prison sentences with a minimum of eight days and maxima ranging from one year (e.g., the Environmental Permitting Decree) to five years (e.g., the Waste Decree). ${ }^{3}$

When determining sanction magnitudes, criminal courts reserve the option to suspend sanction execution, either partially or completely. Similar to a postponement of a verdict, a suspension always

\footnotetext{
${ }^{3}$ In Belgium, the fine amounts mentioned in legislation are multiplied by a legal correction factor ("opdeciemen") to counter the effects of monetary depreciation. This correction factor equaled 5 from 2002 until 2004 and 5.5 from 2005 until 2011 and this factor has equaled 6 since 2012. The identified minimum and maximum fines do not reflect this factor.
} 
includes a probationary period of one to five years. Criminal legal doctrine classifies both postponement and suspension as "favors", representing expressions of leniency. Unlike postponement, suspension is a widespread option in the sanctioning possibilities of criminal courts throughout the EU, where it is commonly seen as a means to prevent recidivism (European Commission, 2004).

As the last step in the sanctioning decision, once the criminal court has decided to impose at least one principal sanction, suspended or not, the court can also impose one or more additional sanctions. The additional sanctions can be punitive or remedial in nature, with the remedial ones typically aiming to stop or at least mitigate further damage to the environment. The most common additional sanctions are the forfeiture of illegally acquired benefits, waste removal orders, and the injunction to cease a business operation for safety reasons. Forfeiture of illegally acquired benefits fits with the widespread belief that "crime should not pay" (Bowles et al., 2005). Under Belgian law, this sanction can only be imposed if explicitly requested by the public prosecutor.

Belgian law identifies only one factor that must influence the sanctioning decision: the criterion of proportionality with "the seriousness of the offense", which indicates that the criminal judge must punish "in proportion to the seriousness of the offense". This basic sentencing criterion, developed by the Belgian Supreme Court, applies to all types of criminal cases. It includes two sub-criteria: (1) the objective gravity of facts, which is rated by the extent to which the unlawful activities harmed or might have harmed the public interest, and (2) the culpability of the defendant.

Individuals, as well as legal persons, who consider themselves harmed by the offense under consideration, can become a civil party in a criminal case. If a defendant is convicted, the judge will also rule on civil claims and, if relevant, award damages.

\section{Data}

To assess the impact of legal representation on court outcomes, we use the Environmental 
LawForce database (www.environmental-lawforce.ugent.be). This database records the complete environmental case load from January 1, 2003, to December 31, 2006, for seven of the - then existing thirteen judicial districts located in Flanders - Brugge, Dendermonde, Gent, Ieper, Kortrijk, Oudenaarde, and Veurne - which represent the courts of first instance, and the relevant court of appeal, located in Gent, representing one of the five Belgian courts of appeal. In addition, this database records the complete punitive administrative case load (fines) of the Brussels environmental administration for the same time period.

The database includes information on 1,034 criminal cases, of which 912 were decided by the courts of first instance, while 122 were concluded in appeal (Billiet et al., 2014). In total, 1,617 defendants were tried in these 1,034 criminal prosecutions: 1,352 only in first instance and 265 both in first instance and in appeal. Some $80 \%$ of the defendants are individuals, while $20 \%$ are legal entities. Since each defendant can face several accusations, the cases include 3,561 accusations, of which 3,004 were dealt with in first instance and 557 in appeal. The sampled environmental case load focuses on the environmental legislative acts listed in the appendix.

For the current study, we limit the dataset to the 1,330 decisions made by the criminal courts of first instance that deal with individual defendants. In Belgium, only the public prosecutor can initiate settlement offers, which take the form of a one-time take-it-or-leave-it offer. Consequently, in principle, legal counsel cannot negotiate a settlement with the public prosecutor. Thus, the presence or absence of legal counsel does not influence the likelihood of a case going to court. However, exceptions to this general rule occasionally arise. We purposively avoid cases brought before the court of appeal because they most likely are distinctively different, demand additional analysis, and offer a much smaller sample (122 cases with 265 defendants of which only 22 did not hire a lawyer). ${ }^{4}$ We purposively exclude legal

\footnotetext{
${ }^{4}$ By ignoring appeals, our empirical estimates offer only a lower bound on the value of hiring a lawyer since we do not consider the value of using a lawyer to increase the likelihood of an appeal if the judge imposes a harsh
} 
entities since these defendants nearly always hire legal representation. The resulting sample consists of two types of individuals: professional individuals, whose infractions tie to professional work at businesses or government entities, and private individuals, whose infractions tie to an individual's private life. Professional individuals represent $44 \%$ of the dataset (585), while private individuals represent 56\% (745). Approximately one in five defendants had already been convicted of one or more environmental or other criminal offenses before their court trials: $22 \%$ of the prosecuted professionals and $20 \%$ of private individuals.

By exploring demographic characteristics of the prosecuted professionals, we demonstrate that $91 \%$ were male and $95 \%$ were of Belgian nationality. These professionals were 47 years old on average. For prosecuted private individuals, $80 \%$ were male and $89 \%$ were of Belgian nationality. Private individuals were 44 years old on average.

Regarding the prevalence of legal representation, $59 \%$ of defendants were assisted by a lawyer during court proceedings. Specifically, $77 \%$ of prosecuted professionals (451) employed a lawyer, while only $45 \%$ of private individuals (332) did so. In Belgium, defendants, even those facing the possibility of a prison sentence, are not legally required to be represented by a lawyer and can always decide to represent themselves in court (FOD Justitie, n.d.). Moreover, two features of the Belgian legal system explain why defendants would choose to eschew legal representation. First, lawyers are typically paid based on fixed (hourly) rates rather than through contingency fees. ${ }^{5}$ Second, the justice system does not automatically provide a lawyer if the defendant cannot afford one. ${ }^{6}$

sanction. As important, we acknowledge that the effect of hiring a lawyer may differ between cases decided by first instance courts and cases concluded in appeal. Thus, we do not claim that our results generalize to all cases prosecuted in the state of Flanders during our sample period.

5 A contingency fee is payable only if there is a favorable result. Thus, the contingency fee makes litigation possible for people who could not otherwise afford it (George, 2006).

${ }^{6}$ Still some insurance policies include the free provision of legal aid. Moreover, low income defendants are able to apply for free legal aid from the government (FOD Justitie, n.d.). However, transaction costs are typically substantial for both options. 
Table 1 summarizes the distribution of different case outcomes. For the full sample, we see that $88 \%$ of defendants were found guilty, i.e., convicted. Of the guilty defendants, $85 \%$ received a fine and $4 \%$ were confronted with a forfeiture of the illegally acquired gains. In addition, the criminal court imposed a prison sentence against $9 \%$ of convicted defendants and imposed a problem solving or remedial sanction on $19 \%$ of convicted defendants. The strong majority of these remedial sanctions were clean-up orders related to waste offenses. In waste cases, judges are legally required to impose a cleanup order under commonly applicable circumstances. Given this requirement, we examine this type of sanction as a robustness check since the presence of a lawyer should not influence the judicial decision to impose a remedial sanction at least not in the strong majority of cases.

\section{Econometric Framework}

This section describes our econometric framework by depicting the dependent variables, primary regressor, and control factors.

In order to study the effect of legal representation on case outcomes related to environmental crime in Flanders, we analyze the described data at the level of an individual defendant. For each defendant, we possess information regarding a variety of outcomes, i.e., court decisions. The first group of outcomes include binary decisions made by the court: (1) whether or not to find a defendant guilty, (2) whether or not to impose a fine, (3) whether or not to impose a monetary sanction (i.e., a fine and/or a forfeiture of illegally acquired gains), (4) whether or not to issue a problem solving or remedial sanction, and (5) whether or not to impose a prison sentence. We condition the latter four binary decisions on a guilty verdict. Recall that the fourth decision made by the judge is constrained by legal rules; therefore, we choose to interpret the analysis of this decision as a robustness check. The second group of outcomes includes court decisions about the quantitative magnitudes of imposed sanctions, conditioned on a guilty verdict: (1) effective fine, (2) suspended fine, (3) effective monetary sanction, 
(4) suspended monetary sanction, (5) effective prison term, and (6) suspended prison term. Again, we measure the effective magnitude as the difference between the initial sanction magnitude and the suspended magnitude. We measure the monetary sanction magnitude as the sum of the fine magnitude and the forfeiture of illegally acquired gains magnitude.

Our primary regressor is the presence (versus the absence) of a lawyer. Beyond this legal representation factor, we add six sets of control factors:

(1) basic (e.g., year, quarter, court location),

(2) culpability (e.g., count of proved accusations),

(3) damages (including pollution categories),

(4) legal adjustments (e.g., previous conviction),

(5) mechanics of the legal process (e.g., avenue of violation discovery), and

(6) defendant personal characteristics (e.g., age).

Appendix Tables A-1 and A-2 identify the full set of control factors. From these groups of control factors, we construct six models (i.e., regressor sets) based on the order of the control factors shown above. Accordingly, Model 1 includes only basic control variables, Model 2 includes both the basic and the culpability control variables, Model 3 includes control factor groups 1 through 3 , and so on. We use these different models to assess the robustness of our conclusions. To estimate the binary outcomes, we employ a probit estimator. Sanction magnitudes are censored from below at zero. To estimate these censored outcomes, we employ a Tobit estimator. ${ }^{7}$

Since multiple defendants may be involved in a single case, our estimation clusters the standard

\footnotetext{
${ }^{7}$ Alternatively, we could implement a semilog specification in which each sanction magnitude-based dependent variable is logged. However, implementation of this specification requires replacing any zero value with a positive value. This replacement, by its nature, is arbitrary. We employ a Tobit estimator because zero values are sufficiently common in our sample. Rather than logging the bottom-censored dependent variables, we prefer to focus on the linear specification so we avoid the concern about arbitrarily selecting a replacement for zero values.
} 
errors at the level of a single case. ${ }^{8}$

As our identification strategy, we distinguish between cases with legal representation and cases without representation. This strategy does not exploit any random assignment of legal counsel or natural experiment. Instead our strategy relies on exogenous variation in legal representation. However, the presence of a lawyer may be an endogenous regressor, which would bias our estimate. We return to this possible, if not likely, bias in sub-section 6.4.

\section{Econometric Results}

In this section, we first present the econometric results generated by estimating the link from the presence of lawyer to the observed court decisions. Second, we discuss the quality of the results and assess the effects of the control factors. Third, we comment on the implications of the results for a defendant's decision to hire a lawyer for an environmental criminal case in Flanders. Fourth, we assess the impact of any bias stemming from the possible, if not likely, endogeneity of lawyer presence.

\subsection{Effects of Legal Representation}

In this section, we present the econometric results for the different case outcomes. Firstly, Table 2 presents the estimation results for the binary outcomes. Assessment of these estimates allows us to investigate the impact of legal representation on the probabilities of (1) being convicted and (2) receiving a particular sanction. ${ }^{9}$ Secondly, Table 3 presents the estimation results regarding the sanction levels imposed on convicted defendants. For each of the dependent variables, we estimate six different models representing a growing number of control variables, as explained in sub-section 5.1. Tables 2 and 3

\footnotetext{
${ }^{8}$ Joint estimation of our multiple dependent variables would improve the efficiency of our estimates. However, the binary and censored nature of our dependent variables greatly constrains implementation of any joint estimation. Fortunately, our results reveal statistically significant relationships between the primary regressor, legal representation, and most of the dependent variables. Thus, improved efficiency is not critical.

9 Table 2 does not report the marginal effect magnitudes derived from these coefficients for the purposes of assessing the economic importance of our results. (By construction, the reported coefficient signs are identical to the marginal effect signs.) Instead, we assess the economic importance of our results stemming from the Tobit estimation of sanction magnitudes.
} 
display only information on the coefficient for our primary regressor - lawyer presence, along with estimation summary statistics. Appendix Tables A-1 and A-2 display the full regression results for Model 6 for the binary outcomes and bottom-censored outcomes, respectively. The full regression results for Models 1 through 5 reveal highly similar results for the control factors.

To start, we investigate the probability that a defendant receives a guilty verdict. If the criminal court finds supporting facts and liability is proven, a guilty verdict follows. Otherwise, the defendant is acquitted. We find that the presence of a lawyer significantly lowers the probability of being found guilty, except for Model $5(\mathrm{p}=0.119)$. This claim notwithstanding, we acknowledge that our estimation does not control for selection bias; thus, our estimates need not reflect causal effects.

Following a guilty verdict, the court decides on whether or not to impose a particular sanction and the magnitude of any imposed sanction based on the court's perception of the appropriate sanction(s) for a particular defendant. As noted above, we distinguish across four types of sanctions: (1) fine, (2) monetary sanction, (3) prison sentence, and (4) problem solving or remedial sanction. For the former three types, we distinguish between effective sanction magnitudes, i.e., initial level less the suspended amount, and suspended sanction magnitudes. In all cases, we acknowledge that our estimation does not control for selection bias; thus, our estimates need not reflect causal effects.

Firstly, we focus on the fine results. We find that the presence of a lawyer significantly reduces the probability that the court imposes a fine as punishment. Legal representation also influences the magnitude of the fine that is imposed. Assessing the effective fine level, we see that the presence of a lawyer lowers fine level (except in Model 1). Lawyers seem to be able to reduce the fine levels by 2,000 to 3,000 euro. However, legal representation increases the suspended fine level (except in Model 1). Apparently, lawyers successfully lower the effective fine by increasing the suspended fine portion. Recall that following a suspension, an offender who does not relapse within the probationary period of 
one to five years will not have to bear the imposed sanction.

Secondly, we examine the monetary sanction imposed by the criminal court. Again, the presence of a lawyer has a significantly negative impact on the likelihood of receiving a monetary sanction. As with fine levels, the presence of a lawyer influences monetary sanction levels, decreasing the effective monetary sanction magnitude, while increasing the suspended monetary sanction magnitude.

Thirdly, we find that the presence of a lawyer also affects the likelihood that a court judge decides to incarcerate a convicted defendant. Represented defendants face a lower probability of receiving a prison sentence. Moreover, the presence of a lawyer significantly reduces the length of the effective prison sentence yet does not appear to influence the length of the suspended sentence.

Fourthly, we explore the probability that a court judge imposes a problem solving sanction such as mandatory waste clean-up. As expected, legal representation does not seem to influence the probability of receiving such a remedial sanction. Statistically, the coefficient representing the presence of a lawyer is not significant.

Finally, our conclusions regarding the estimated impacts of legal representation on court decisions are strongly robust across (almost) all of the estimated models, as shown in Tables 2 and 3. The presence of a lawyer significantly reduces the likelihood of being convicted, the likelihood of receiving a monetary and/or non-monetary sanction, as well as the level of these sanctions. Reflecting on this positive impact of hiring a lawyer, we speculate that lawyers improve legal outcomes due to their superior knowledge of legislation, professional acumen for interpreting legal texts, and experience with court proceedings (Goodman-Delahunty et al., 2010; Eigen and Listokin, 2012). Alternatively, lawyers might improve outcomes because lawyers "speak the language of the court", present legal cases in a more structured and objective manner, and improve the probability of a successful appeal. Finally, the court may also interpret the presence of a lawyer as a signal that the offender is taking the case seriously. 


\subsection{Control Factors}

In this section, we comment on the broader set of estimation results. For all factors, we acknowledge that our estimation does not control for selection bias; thus, our estimates need not reflect causal effects. As revealed by the Wald tests and F-tests of slope coefficients, shown in Tables 2 and 3, we find solid results for each regression equation, except for suspended fine and suspended monetary sanction magnitudes. We observe no particular temporal patterns since the year and quarter dummies are mostly insignificant. Based on the court indicator coefficients, we observe some evidence that the court in Brugge imposes fewer and lower sanctions for environmental crime compared to the other courts. The courts in Ieper, Veurne and Oudenaarde seem to be less likely to use suspended fines or to impose higher suspended fine levels. Thus, courts, i.e. judges, seem to possess their own preferences regarding the sanctioning decisions with respect to environmental crime.

Regarding the remaining control variables, we find the correct signs where $a$ priori expectations are clear. Defendants with a previous conviction face a significantly higher likelihood of sanction imposition and receive higher sanctions. We also observe that more serious offenses are more likely to prompt a sanction and lead to higher sanction levels. We measure the seriousness of an offense using several indicators, such as the number of proven accusations, the duration of the offense, the intentionality of the offense, the presence of explicitly mentioned gain seeking behavior, the presence of harmed civil parties, and the priority status of the offense. ${ }^{10}$ The importance of the seriousness of the offense is supported by the observation that courts punish offenders who undertake voluntary measures

\footnotetext{
${ }^{10} \mathrm{We}$ acknowledge that number of proven accusations also represents a court outcome that precedes the judges' decisions over the verdict and sanctions. Thus, this factor may be endogenous with respect to the explored dependent variables. Since it represents only a control factor, we do not attempt to assess or address its possible endogeneity. Instead, we assess whether its exclusion from Models 2 through 6 influences our conclusions. Reestimation of Models 2 through 6, while excluding the count of proven accusations as a regressor, generates lawyer presence coefficient signs identical to those reported in Tables 2 and 3, highly similar coefficient magnitudes, and very similar p-values. This robustness is not surprising since this regressor proves insignificant in most of the reported estimation results; see Appendix Tables A-1 and A-2 for the Model 6 estimates.
} 
to limit the damages from an incident, clean up the incident, or solve the underlying problem less harshly. The court apparently accepts remedial actions and current compliance as attenuating circumstances.

We find statistical significance for several other factors. Compared to private individuals, professional defendants face a lower probability of being convicted and of receiving monetary sanctions. Professionals also receive lower effective and suspended fine levels and prison sentences. Some differences depend on the industrial sector in which a professional defendant works. However, these results are not straightforward to interpret. Still we observe that defendants working in the accommodation and food sectors are more likely to be convicted and to receive sanctions when convicted and receive higher sanctions. Further, we find that the type of pollution influences court decisions. While waste-related offenders appear less likely to be convicted, they are more likely to receive sanctions, as well as mandatory clean-up orders. These offenders also bear higher sanctions.

Finally, socio-demographic factors apparently influence the sanctioning of environmental crime to only a limited extent. We observe no gender effects. We observe some age effects: weak evidence reveals that older defendants are less likely to receive a prison sentence and bear higher effective fines. We observe some limited nationality effects: weak evidence reveals that Belgian citizen are more likely to be found guilty, more likely to receive a problem solving penalty, and receive higher suspended sanctions.

\subsection{Implications for the Decision to Hire a Lawyer}

In order to assess whether or not it is a sound decision to hire a lawyer, we investigate the expected effect of legal representation on court decisions and compare these effects to the expected cost of hiring a lawyer. This investigation is merely a back-of-the-envelope calculation rather than extensive cost-benefit analysis.

First, we calculate the expected cost of hiring a lawyer in Flanders. The costs of hiring a lawyer 
typically consist of two parts: a representation fee (euro per hour worked on the case) and a charge to cover operational costs (euro per case). A study of the Flemish Bar Association finds that more than half of the lawyers charged a fee, excluding VAT, between 75 and $150 €$ per hour in 2006, with an average of $100 €$ per hour for individuals, $125 €$ per hour for companies, and $134 €$ per hour for the government (Vacature, 2010). This representation fee applies in addition to operational charges for communication, file management, and transportation costs. These one-time operational charges can easily amount to more than several hundred euros (DAS, 2008). Therefore, we conservatively estimate operational representation costs at 500 euro.

Next, we assess the marginal effects of the presence of a lawyer. As with the underlying coefficient estimates, since our estimation does not control for selection bias, our estimated marginal effects need not be causal. We begin our assessment with the Tobit estimates relating to the effective fine since this effect is already expressed in monetary terms (see Table 3). We find that legal representation is expected to lower the effective fine by 2,282€ (in Model 4) to 2,922€ (in Model 3) for a given offense. Using the most complete model (Model 6), we estimate a 95\% confidence interval for the lawyer presence coefficient of $[-4827,-241]$. Thus, the expected financial benefits of hiring a lawyer range between $241 €$ and $4,827 €$ with $95 \%$ confidence. Based on the lower benefits estimate of $241 €$, given operational charges of $500 €$, hiring a lawyer is not worth the hourly fee of $100 €$, regardless of the expected number of hours billed. However, based on the upper benefits estimate of $4,827 €$, a lawyer is worth the hourly fee of $100 €$ as long as no more than 43 hours are billed. ${ }^{11}$

As a broader measure, we assess the marginal effects of lawyer presence on the effective monetary sanction (see Table 3). We find that legal representation lowers the effective monetary sanction

\footnotetext{
${ }^{11}$ As noted above, since our analysis does not explore appealed cases, these calculations only represent a lower bound on the value of hiring a lawyer because they ignore the value of using a lawyer to increase the likelihood of an appeal when relevant.
} 
by $2,054 €$ (in Model 4) to 3,006 $€$ (in Model 2) for a given offense. Using the most complete model (Model 6), we estimate a 95\% confidence interval for the lawyer presence coefficient of [-5047, -343]. Thus, the financial benefits of hiring a lawyer range between $343 €$ and 5,047€ with $95 \%$ confidence. Based on the lower benefits estimate of $343 €$, given operational charges of $500 €$, hiring a lawyer is not worth the hourly fee of $100 €$, regardless of the expected number of hours billed. However, based on the upper benefits estimate of 5,047 $€$, a lawyer is worth the hourly fee of $100 €$ as long as no more than 45 hours are billed.

Beyond the impact on the effective fine and effective monetary sanction, legal representation also reduces the probability of conviction, the probability of receiving a prison sentence, as well as the level of that prison sentence. In addition, as legal representation reduces the probability of being convicted, it also reduces the social stigma attached to a criminal record (Billiet and Rousseau, 2014). For individuals working in positions of responsibility where trust is critical, the stigma of a criminal conviction might be severe, implying a substantial loss of future earnings (e.g., Nagin and Waldfogel, 1995). Moreover, the involvement of a lawyer is valuable since a lawyer is better able to preserve the grounds for appeal. Taking all these effects together clearly increases the value of hiring a lawyer.

\subsection{Impact of Endogeneity Bias on the Effect of Legal Counsel}

The presence of legal counsel may be endogenously determined. Inclusion of an endogenous regressor clearly generates a bias in the regressor's coefficient estimate. This bias may be large enough to undermine our ability to draw the correct qualitative conclusion: legal counsel effectively improves court outcomes for the defendant.

Nearly all of our empirical estimates reveal a negative coefficient for the presence of legal counsel when the outcome is bad for the defendant, e.g., guilty verdict, and a positive coefficient when the outcome is good, e.g., suspended fine magnitude. For nearly all of the court outcomes, the negative 
coefficient on a bad outcome and positive efficient on a good outcome proves statistically significant, supporting the conclusion that legal counsel helps defendants. However, the possible endogeneity bias may be driving this conclusion.

Without speculating on the size of the endogeneity bias, we are able to determine the size of the bias needed to undermine our conclusion. Specifically, we can identify the size of the bias needed to remove the statistical significance of estimated coefficient, which we label as the "bias threshold". If the actual bias magnitude lies below this bias threshold, then we would still draw the same conclusion. If the actual bias magnitude lies above this threshold, then the bias effectively prompts us to draw an erroneous conclusion.

Towards this end, we establish the critical significance level as $10 \%$. The associated t-test statistic equals 1.65 . We assume a fixed standard error for each coefficient. Then we can easily identify the coefficient magnitude consistent with a t-test statistic of 1.65 , which we label as the "critical coefficient". We then calculate the absolute difference between the critical coefficient and the actual coefficient. Finally, we calculate the ratio between the absolute difference and actual coefficient. We interpret this ratio as the "relative bias threshold".

For each outcome, we consider six regressor sets. To calculate the bias threshold, we focus on the broadest regressor set (Model 6). Our assessment is quite robust to consideration of other models.

We focus exclusively on outcomes where legal counsel apparently proves helpful. Consider first binary outcomes. Regarding the verdict, the relative bias must be at least $10 \%$ in order to overturn our conclusion. In other words, if one or more unobserved variables imply that defendants with legal counsel are less likely to be convicted than defendants without legal counsel, this selection bias would only overturn our finding if the associated decrease is at least $10 \%$ relative to the estimated coefficient. In contrast, the relative bias must be $66 \%$ to overturn our conclusion regarding fine imposition. Similarly, 
the relative bias must be $65 \%$ for monetary sanction imposition. In between, the relative bias must equal at least $25 \%$ to overturn our prison sentence conclusion.

Next consider quantitative outcomes. For the effective fine magnitude, the relative bias threshold is $34 \%$. The threshold is slightly lower for the suspended fine magnitude at $22 \%$. The relative bias threshold for effective monetary sanction magnitude at $33 \%$ is highly similar to the effective fine magnitude threshold. Moreover, the suspended monetary sanction magnitude has a threshold nearly identical to the suspended fine magnitude threshold at $22 \%$. As the largest threshold, the relative bias for the effective prison term magnitude must equal at least $55 \%$ to overturn our conclusion.

With the exception of the verdict outcome, these relative bias thresholds seem quite sizable but not outside of any reasonable range.

\section{Views from Environmental Law Practice in Flanders}

The estimation results reveal several differences in the sanctioning of defendants with a lawyer and those without a lawyer. These findings may reveal two observationally equivalent situations: (1) defendants with or without a lawyer are different, or (2) lawyers make a difference. (Of course, both situations may hold.) In order to gain more insight into these two situations, we collected information on views held by defense lawyers, public prosecutors, and judges working in Flanders.

\subsection{Data Collection and Description of Dataset}

We designed an online survey in Qualtrics to gain insight into the role of lawyers. This survey included closed- and open-ended questions regarding the selection of clients by lawyers, the difference between defendants with and without legal representation, and the impact of lawyers on criminal proceedings. We contacted 110 practitioners through electronic mail on May 17, 2019 and asked respondents to participate by following a link embedded in the email message. ${ }^{12}$ We sent no reminders.

\footnotetext{
${ }^{12}$ We contacted 61 respondents personally and one respondent forwarded the invitation to a mailing list of some 50 environmental magistrates.
} 
Of the 110 contacted practitioners, 30 followed the survey link, with 26 respondents providing useful information for our analysis. ${ }^{13}$ The final sample consists of 13 lawyers, 3 prosecutors, and 10 judges (7 lower court judges and 3 higher court judges). Sixteen respondents indicated that they deal with environmental cases frequently (8) or very frequently (8).

\subsection{Insight Gleaned from Survey Responses}

\subsubsection{Lawyers' Selection of Clients}

From the gathered survey data, we glean insight into the process that lawyers use to select their clients. The thirteen lawyers in our sample are usually directly contacted by new clients, but lawyers also obtain new clients through referral or assignment by their law firms. When asked whether they would agree to represent someone who contacted them regarding an environmental case, four respondents would always agree and the other nine would sometimes do so. The main reason to accept or reject an environmental case is the fit with the lawyer's area of expertise. The main reasons for possibly refusing a case relate to a defendant's attitude. As examples of this factor, respondents offered these concerns:

"a guilty defendant should be willing to voluntarily remediate the damage",

"a guilty person should not strongly dispute his/her guilt",

"a defendant should not disagree without rational arguments", and

"a client should not manifest bad faith".

Two respondents also mentioned that it was important that the case was in line with the values and reputation of the lawyer's firm.

Figure 1 confirms these findings by displaying the importance of several factors in a lawyer's decision to select a new client. Past experience with legislation is the most important factor, followed by the personal characteristics of the client. In third place, the likelihood of winning a case is also important.

\footnotetext{
${ }^{13}$ We exclude four responses from the analysis: two respondents only answered three or fewer questions, one respondent merely participated in a civil procedure, and one respondent was only a legal graduate (not a lawyer).
} 
The violated legislation, expected time cost, seriousness of the offense and past experience with the court also play roles a lawyer's decision to accept a case.

Some of these factors are problematic for our reliance on the exogeneity as our identification strategy for exploring the impact of legal counsel, while other factors seem fine. To prove problematic, a factor must influence court decisions (or at least correlate with court decisions), prove important for client selection, and be unobservable (i.e., excluded as a control factor). Our analysis fails to control for the likelihood of winning, expected financial return, and culpability, yet these factors at least correlate with court decisions. No more than six lawyer respondents identify these factors as important. While less than a majority, this presence is still notable. As another meaningful factor, our analysis attempts to control for offense seriousness, but our efforts may be insufficient. This factor surely influences court judgements. Fortunately, only six of the 13 lawyers find this factor important. Past experience with legislation is very important for most lawyers. However, this factor does not speak to the defendant but instead the lawyer. Similarly, past experience with the court is important but speaks to the lawyer. In contrast, client personal characteristics clearly relate to the defendant. A majority of respondents find this factor important for client selection. Fortunately, our analysis controls for this factor at least crudely. We also control for the violated legislation; moreover, only five of the 13 lawyers find this factor important. Lastly, we argue that expected time cost is not correlated with court decisions.

\subsubsection{Comparison of Defendants with and without Lawyer}

We also use the survey to examine whether court participants perceive defendants with or without lawyer as different. To this end, we presented several statements to the survey respondents. Respondents could agree or disagree with these statements based on a 5-point Likert scale. Figure 2 presents the results. The figure sums the answers 'agree' and 'fully agree' into one group and sums answers 'disagree' and 'fully disagree' into a second group. Figure 2 presents separately the opinions of lawyers, 
prosecutors, and judges.

The first statement explicitly speaks to the basic difference. Most respondents (21 out of 26) disagree with the statement that there is no difference between defendants with or without lawyer. The two respondents who agree with the statement were judges, probably reflecting the viewpoint that all defendants are treated equally in their courts. Looking closer at possible perceived differences between defendants, respondents generally agree that better prepared defendants are more likely to hire a lawyer. Regarding the impact of income and education, opinions are more heterogeneous. Approximately the same proportion of lawyers and prosecutors agree or disagree with the statement that respondents with a lawyer are more wealthy or better educated, while slightly more judges agree than disagree with these statements. Half of the respondents (13) are indifferent regarding the statement that defendants with a lawyer are more likely to have Belgian nationality; still a sizeable part of the sample (10) disagree with this statement. Finally, most respondents (17) disagree with the statement that defendants with a lawyer are more likely to be guilty. In response to the open-ended question regarding other differences between defendants with and without lawyers, one judge mentioned that "defendants without a lawyer are usually prosecuted for less serious crimes, which are more likely to attract less severe penalties".

As with lawyers' selection of clients, some of these factors are problematic for our reliance on exogeneity as our identification strategy. To prove problematic, a factor must influence or correlate with court decisions, differ between defendants with and without legal counsel, and not be captured by a control factor. Clearly the likely guilt of a defendant should influence court decisions and our analysis does not control for likely guilt. A strong majority of respondents disagree with the relevant statement. Thus, this factor seems problematic. Similarly, a defendant's preparation and education may correlate with court decisions and our analysis fails to control for these factors. With the exception of judges, a strong majority of court participants agree with the preparation statement. Similarly, a strong majority 
of participants, with the exception of judges, agree or disagree with the education statement. These factors may seem problematic. While income could influence court decisions indirectly, we argue that income should play no role conditional on a defendant securing legal counsel. (In other words, income helps a defendant to hire a lawyer, as confirmed by court participant's views, but not otherwise; consequently, we rule out the bribing of judges.) Thus, this factor should not prove problematic. Lastly, we control for Belgian nationality so this factor cannot prove problematic.

\subsubsection{Perceived Impact of Lawyer}

In order to gain more insight into the role of a lawyer in criminal proceedings, we asked the respondents whether they would recommend persons who face prosecution to secure legal counsel. Most respondents (17, of which 11 are lawyers) would certainly recommend legal counsel, while the remaining (8, of which 2 are lawyers) would probably do so. Respondents mentioned several motivations to support this recommendation:

- environmental legislation is technical and specialized,

- better protection of a respondent's rights,

- main and side issues are not always easy for a defendant to distinguish, and

- defendants usually possess too little knowledge of criminal law (e.g., ignorance of sanctions that they can face).

Some quotes are especially illuminating in this respect. One lawyer stated: "There are few things as sad as seeing someone try to defend oneself, where you see or feel that important arguments are getting lost." As another lawyer stated: "It is (...) a good idea to work with the defendant to ensure that the truth is revealed as accurately as possible and that a correct defense strategy can be selected". One judge made the following point: "Regulation is complex; the lawyer is familiar with the system; he often knows the judge and can assess what is and what is not possible." 
Finally, we asked respondents how they perceive the role of certain mechanisms by which legal representation impacts court decisions (see Table 4). Responses reveal a consensus that lawyers help defendants by offering a better understanding of procedures, as well as the content of cases. Most respondents also agree that lawyers speak the language of the courts and prosecutors and are able to present the case in a more structured manner. However, respondents also indicate that lawyers do not save time for defendants. Most interesting, respondents are less certain about whether legal representation can lower a defendant's expected sanction. Most respondents indicated 'maybe' or 'no' when asked whether defendants with a lawyer have a lower probability of receiving a prison sentence or a higher probability of settlement or acquittal. The same pattern appears when assessing whether defendants with a lawyer face less series sanctions and lower expected fines. The largest difference in opinion regards the statement that 'having legal representation is a signal that the defendant takes the case seriously'. Seven lawyers and one prosecutor agree with this statement, yet two lawyers and three judges disagree. This contrast seems to indicate that lawyers are more optimistic about their role than judges are. All these differences notwithstanding, one quote by a prosecutor reminds us that general conclusions are difficult to draw: "One must always take the specific nature of each case into account, which makes it difficult to draw a general line on the likely impact of having or not having the assistance of a lawyer."

This insight on mechanisms linking legal counsel to court decisions helps to confirm that our empirical results are not spurious. Instead our results surely reflect the influence of these noted mechanisms.

\subsection{Concluding Remarks about Flemish Practice}

Our assessment of the survey responses reveals some interesting patterns. Firstly, the lawyers in our sample do not automatically take all clients. On the one hand, the fit of the legislation cited in the 
case and the lawyer's area of expertise is central. On the other hand, the attitude of the defendant plays an important role in the acceptance decision. Secondly, court participants perceive defendants with and without lawyers as different. Respondents generally agree that better prepared defendants are more likely to hire a lawyer, while opinions are more diverse regarding the impact of income and education. And most respondents disagreed with the statement that defendants with a lawyer are more likely to be guilty. Thirdly, considering the perceived impact of legal representation, respondents mainly see benefits in reducing transaction costs and informational bottlenecks. Lawyers know the legislation and the system so defendants can benefit from the lawyers' expertise, especially in more technical and complex environmental cases. Regarding the possibility of having a positive effect on the probability and magnitude of sanctions, the role of a lawyer seems less straightforward and more dependent on the actual case characteristics.

Most important for our analysis, our assessment of survey responses (1) reveals that defendants with or without a lawyer may differ in only some dimensions not captured by the control factors in our empirical analysis, while many dimensions prove unimportant or are important but captured by control factors, and (2) confirms the role of certain mechanisms by which legal representation impacts court decisions.

\section{Summary, Policy Implications, and Future Research}

Using data from all environmental criminal cases prosecuted in East and West Flanders between 2003 and 2006, we analyze the effect of legal representation on criminal case outcomes, i.e., court decisions, e.g., prison term. Our empirical findings appear to show that, when defendants who are prosecuted for environmental crimes in Flanders are assisted by legal counsel in court, they experience significantly more beneficial outcomes than defendants without counsel. Represented defendants are much less likely to be convicted, face a significantly lower likelihood of sanction imposition, and receive 
lower sanctions. Nevertheless, we acknowledge that the presence of a lawyer may not be exogenous to the studied court decisions. Thus, the identified differences in outcomes may not be attributable solely to the presence of legal counsel due to the influence of unobserved factors on both the decision to hire a lawyer and the court judgments. Moreover, due to the complexity of the legal setting, our results most likely do not generalize to other contexts. Since past studies faced a similar limitation, our study is valuable to investigate the value of legal counsel in the context of environmental crimes in a civil law country.

Of course, the decision to pay for a lawyer may not be financially wise. When compared to the hourly fee of a lawyer, our estimation results do not unequivocally support the recommendation for environmental offenders in Flanders to hire a lawyer. Based on the $95 \%$ confidence interval estimated for the legal representation coefficient in the case of fines, we can conclude that hiring a lawyer is either financially imprudent or prudent as long as the lawyer bills no more than 43 hours, which may be reasonable for the majority of cases argued in our sample of criminal prosecution in Flanders. This said, based on the point estimate of the legal representation coefficient, hiring a lawyer generates benefits of $2,863 €$. In this case, a lawyer is worth the hourly fee of $100 €$ as long as no more than 24 hours are billed. This magnitude most likely applies to only a minority of the cases argued in Flanders.

Since lawyers seem to be valuable but expensive, policy makers in Flanders or Belgium could consider promoting their use. For example, creation of an easier procedure to secure access to free (or less expensive) legal counsel could be worthwhile. Some such promotion began after the conviction of the Turkish State by the European Human Rights Court for not providing a suspect with legal counsel prior to or during the first interrogation in the Salduz case (EHRM 27/11/2008). This conviction led to a binding arrest for all EU member states including Belgium. From 2012 onwards, all individuals under arrest have the right to legal counsel during their first interview by the police. The government provides 
legal counsel at reduced fees (or even for free) to suspects with limited means. Still $30 \%$ of eligible suspects waived their right to legal counsel in 2012 (FOD Justitie, 2012). Moreover, this right to legal counsel applies only during the interrogation phase, not during other phases of a legal procedure, such as a court hearing.

As important, while legal representation may be beneficial for individual offenders, it may be detrimental from a societal point of view. The presence of a lawyer may lead to lower than optimal sanctions for environmental crime. Therefore, future research should compare actual imposed sanctions with optimal sanctions based on the extent of environmental harm, the detection probability, and prosecution costs (Polinsky and Shavell, 1979). Further, we recommend that future research compare actual legal costs to the benefits of legal counsel. Lastly, our study estimates only mean effects, yet considerable heterogeneity in the effectiveness of legal representation and lawyer fees surely warrants more detailed analysis. 


\section{References}

Abrams, David and Albert Yoon (2007), “The Luck of the Draw: Using Random Case Assignment to Investigate Attorney Ability," University of Chicago Law Review, 74 (4), pg 10-90.

Almer, Christian and Timo Goeschl (2010) "Environmental crime and punishment: empirical evidence from the German penal code". Land Economics, 86(4), 707-726.

Anderson, James and Paul Heaton (2012), "How much difference does the lawyer make? The effect of defense counsel on murder case outcomes," The Yale Law Journal, 122, pg. 154-217.

Anderson, James, Maya Buenaventura, and Paul Heaton (2019), "The Effects of Holistic Defense on Criminal Justice Outcomes," Harvard Law Review, 132(3), pg. 819-893.

Ater, Itai, Yehonatan Givati, and Oren Rigbi (2017), "The Economics of Rights: Does the Right to Counsel Increase Crime?," American Economic Journal: Economic Policy, 9 (2), pg. 1-27.

Billiet, Carole (2016, in press), "Environmental Law Enforcement in the European Union: benchmarking sanctioning practices in the criminal track," in I. Tchotourian (ed.), Company Law and CRS. New legal and Economic Challenges. Brussels, Bruylant, in press.

Billiet, Carole and Sandra Rousseau (2014), "How real is the threat of imprisonment for environmental crime?," European Journal of Law and Economics, 37 (2), pg. 183-198.

Billiet, Carole, Sandra Rousseau, Annelies Balcaen, and Roel Meeus (2010), "Minnelijke schikkingen voor milieumisdrijven in Vlaanderen," Panopticon, 31 (4), pg. 78-84.

Billiet, Carole, Sandra Rousseau, Annelies Balcaen, Roel Meeus, Karel Styns, Geert De Meyer, Tom Vander Beken, and Luc Lavrysen (2009), "Milieurechtshandhaving: een databestand voor onderzoek naar de penale en bestuurlijke sanctioneringspraktijk," Tijdschrift voor Milieurecht, 18 (2), pg. 128-150.

Billiet, Carole, Thomas Blondiau, and Sandra Rousseau (2014), "Punishing environmental crimes: An empirical study from lower courts to the court of appeal," Regulation and Governance, 8 (4), pg. 472-496.

Blondiau, Thomas and Sandra Rousseau (2010), "The impact of the judicial objective function on the enforcement of environmental standards," Journal of Regulatory Economics, 37 (2), pg. 196-214

Blondiau, Thomas, Carole Billiet, and Sandra Rousseau (2015), "Comparison of criminal and administrative penalties for environmental offenses," European Journal of Law and Economics, 39 (1), pg. 11-35. 
Bowles, Roger, Michael Faure, and Nuno Garoupa (2005), "Forfeiture of illegal gain: An economic perspective," Oxford Journal of Legal Studies, 25 (2), pg. 275-295.

Clarke, Stevens H. and Gary G. Koch (1980), “Juvenile court: Therapy or crime control, and do lawyers make a difference?," Law \& Society Review, 14 (2), pg. 263-308.

Colbert, Douglas L., Ray Paternoster, and Shawn Bushway (2002), "Do attorneys really matter? The empirical and legal case for the right of counsel at bail," Cardozo Law Review, 23 (5), pg. 17191793.

Cooter, Robert D. and Thomas Ulen (2013). Law and economics, Pearson New International Edition. Sixth edition

DAS (2008), Mijn rechten verdedigen? Maar wat gaat mij dat kosten? Retrieved on February 3, 2016 from $\quad$ www.advocatennet.be/uploads/advocatennet/pdf/200811vitaya/Speciaal_4verdediging\%20rechten_wat_gaat_me_dat_kosten.pdf.

Deily, Mary and Wayne Gray (1991), "Enforcement of Pollution Regulations in a Declining Industry," Journal of Environmental Economics and Management, 21 (3), pg. 260-274.

Deily, Mary and Wayne Gray (2007), "Agency Structure and Firm Culture: OSHA, EPA, and the Steel Industry," Journal of Law, Economics, and Organization, 23 (3), pg. 685-709.

Eigen, Zev J. and Yair Listokin (2012), "Do lawyers really believe their own hype and should they?: A natural experiment," The Journal of Legal Studies, 41 (2), pg. 239 - 267.

European Commission (2004), Green Paper on the Approximation, Mutual Recognition and Enforcement of Criminal Sanctions in the European Union. Brussels, COM(2004)334 final, 94p.

Faure, Michael and Katarina Svatikova (2012), "Criminal or administrative law to protect the environment? Evidence from Western Europe," Journal of Environmental Law, 24 (2), pg. 253 286.

Feld, Barry C. (1990), “The punitive juvenile court and the quality of procedural justice: Disjunctions between rhetoric and reality," Crime \& Delinquency, 36 (4), pg. 443-466.

FOD Jusititie (n.d.), "Wat moet u doen als u bent gedagvaard? (What should you do when you are summoned before court?)," retrieved on March 2, 2017, from justitie.belgium.be/nl/wat_moet_u_doen_als/gedagvaarde/bijstand_advocaat.

FOD Justitie (2012), Jaarverslag 2012, retrieved on September 11, 2017, from justitie.belgium.be/sites/default/files/downloads/JAARVERSLAG_2012_NL.pdf

Genn, Hazel and Yvette Genn (1989), The effectiveness of representation at tribunals: Report to the 
Lord Chancellor. London: Lord Chancellor's Department.

George, J. (2006), “Access to justice, costs, and legal aid,” The American Journal of Comparative Law, 54, pg. 293-315.

Goodman-Delahunty, Jane, Pär Anders Granhag, Maria Hartwig, and Elisabeth F. Loftus (2010), "Insightful or wishful: Lawyers' ability to predict case outcomes," Psychology, Public Policy, and Law, 16 (2), pg. 133-157.

Grajzl, Peter, Valentina Dimitrova-Grajzl, and Katarina Zajc (2016), "Inside post-socialist courts: the determinants of adjudicatory outcomes in Slovenian commercial disputes," European Journal of Law and Economics, 41 (1), pg. 85-115.

Greiner, D. James, Cassandra Pattanayak, and Jonathan Hennessy (2013), "The Limits of Unbundled Legal Assistance: A Randomized Study in a Massachusetts District Court and Prospects for the Future," Harvard Law Review, 126(3), pg. 901-989.

Greiner, D. James and Cassandra Pattanayak (2012), "Randomized evaluation in legal assistance: What difference does representation (offer and actual use) make," Yale Law Journal, 121 (8), pg. 2118 2214.

Huang, Kuo-Chang (2008), "How legal representation affects case outcomes: An empirical perspective from Taiwan," Journal of Empirical Legal Studies, 5 (2), pg. 197-238.

Huang, Kuo-Chang, Chang-Ching Lin, and Kong-Pin Chen (2014), "Do rich and poor behave similarly in seeking legal advice? Lessons from Taiwan in comparative perspective," Law \& Society Review, 48 (1), pg. 193-223.

Latreille, Paul, J. Latreille, and K. Knight. (2005), "Making a difference? Legal representation in employment tribunal cases: evidence from a survey of representatives," Industrial Law Journal, 34 (4), pg. 308-330.

Lederman, Leandra, and Warren B. Hrung (2006), "Do attorneys do their clients Justice? An empirical study of lawyers' effects on tax court litigation outcomes." Wake Forest Law Review, 41, pg. 1235.

Levitt, Steven (2004), "Understanding why crime fell in the 1990s: Four factors that explain the decline and six that do not," Journal of Economic Perspectives, 18 (1), pg. 163-190.

Ministry of Justice (2012), Judicial and court statistics 2011.

https://www.gov.uk/government/uploads/system/uploads/attachment data/file/217494/judicialcourt-stats-2011.pdf. 
Monsma, Karl and Richard Lempert (1992), "The value of counsel: 20 years of representation before a public housing eviction board," Law \& Society Review, 26 (3), pg. 627-668.

Nagin, Daniel and Joel Waldfogel (1995), "The effects of criminality and conviction on the labor market status of young British offenders," International Review of Law and Economics, 15 (1), pg. 109126.

Oljaca, Neda, Andrew Keeler, and Jeffrey Dorfman (1998), "Penalty Functions for Environmental Violations: Evidence from Water Quality Enforcement," Journal of Regulatory Economics, 14 (3), pg. 255-264.

Pleasence, Pascoe and Nigel Balmer (2007), "Changing fortunes: results from a randomized trial of the offer of debt advice in England and Wales," Journal of Empirical Legal Studies, 4 (3), pg. 651673.

Polinsky, A. Mitchell and Steven Shavell (1979), "The optimal tradeoff between the probability and magnitude of fines," American Economic Review, 69 (5), pg. 880-891.

Posner, Michael A., Arlene S. Ash, Karen M. Freund, Mark A. Moskowitz, and Michael Shwartz (2001), "Comparing standard regression, propensity score matching, and instrumental variables methods for determining the influence of mammography on stage of diagnosis," Health Services and Outcomes Research Methodology, 2 (3-4), pg. 279-290.Rousseau, Sandra and Thomas Blondiau (2014), “Act-based versus harm-based sanctions for environmental offenders," Environmental Policy and Governance, 24 (6), pg. 439-454.

Raphael, Steven and Rudolf Winter-Ebmer (2001), "Identifying the effect of unemployment on crime," The Journal of Law and Economics, 44 (1), pg. 259-283.

Sandefur, Rebecca L. (2010), “The impact of counsel: An analysis of empirical evidence," Seattle Journal for Social Justice, 9 (1), article 3. Available at: digitalcommons.law.seattleu.edu/sjsj/vol9/iss1/3

Schwab, Steward J. and Theodore Eisenberg (1988), "Explaining constitutional tort litigation: The influence of the attorney fees statute and the government as defendant," Cornell Law Review, 73, pg. 719-784.

Seron, Carroll, Martin Frankel, Gregg Van Ryzin, and Jean Kovath (2001), "The impact of legal counsel on outcomes for poor tenants in New York City's housing court: Results of a randomized experiment," Law \& Society Review, 35 (2), pg. 419-434.

Vacature (2010), Hoeveel vraagt een advocaat voor een uurtje advies? Retrieved on 3 February 2016 
from www.vacature.com/carriere/salaris/Hoeveel-vraagt-een-advocaat-voor-een-uurtje-advies Van den Wyngaert, Chris (2009), Strafrecht, strafprocesrecht en internationaal strafrecht in hoofdlijnen, Antwerpen: Maklu. 


\section{Appendix: Legislation included in the Environmental LawForce database}

The Environmental LawForce database included the case load of the courts for criminal cases where at least one accusation concerned a violation of one of the following parliament acts, cooperation agreements, or associated implementing royal and government ordinances: the Air Pollution Act (1964), Pesticides Act (1969), Surface Water Act (1971), Noise Pollution Act (1973), Flemish Waste Decree (1981), Flemish Groundwater Decree (1984), Flemish Environmental Permitting Decree (1985), Nonionizing Radiation Act (1985), Flemish Manure Decree (1991), Green Taxes Act (1993), Ionizing Radiation Act (1994), Ecolabel Act (1994), Flemish Environmental Policy Decree (1995), Flemish Soil Clean-up Decree (1995), Packaging Waste Cooperation Agreement (1996), Product Standards Act (1998), Marine Environment Act (1999), and Seveso II Cooperation Agreement (1999). The data collection also included violations of exploitation permits based on the Labour Safety Order (1946). During the period covered by the database - 2003 to 2006 - a large number of firms in Flanders still operated under these labour safety permits, which preceded the environmental permits issued under the Flemish Environmental Permitting Decree (1985). 
Figure 1

Factors Potentially Influencing Lawyers' Selection of New Clients

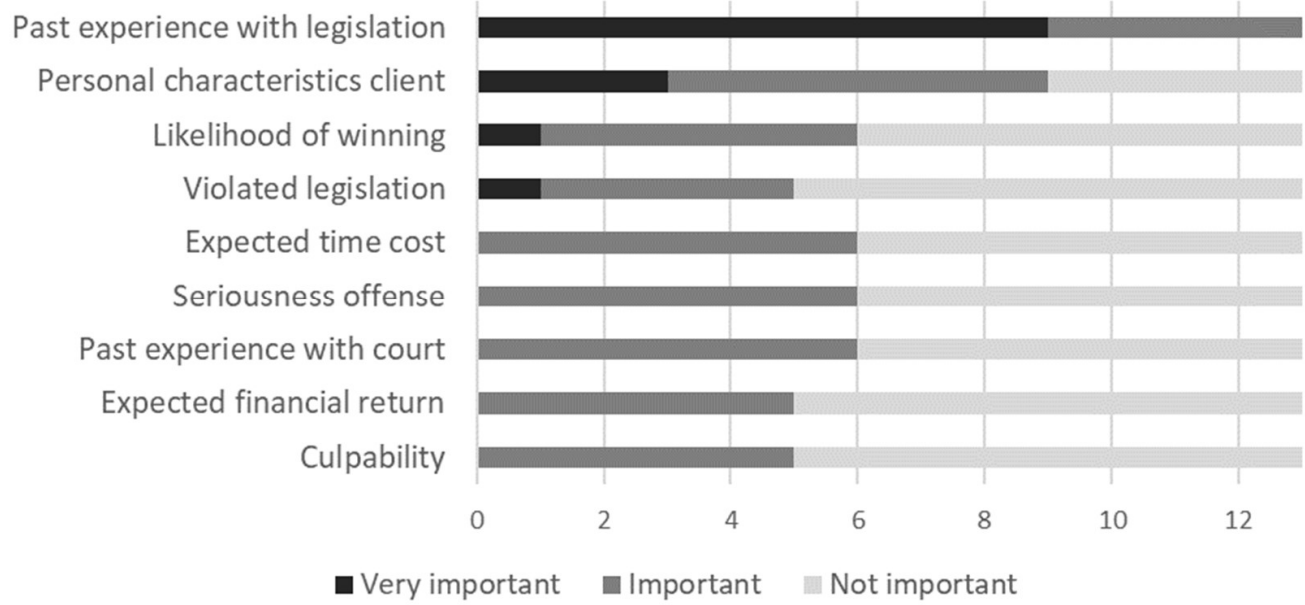


Figure 2

Court Participants' Perceived Differences between Defendants with Legal Counsel and Defendants without Legal Counsel

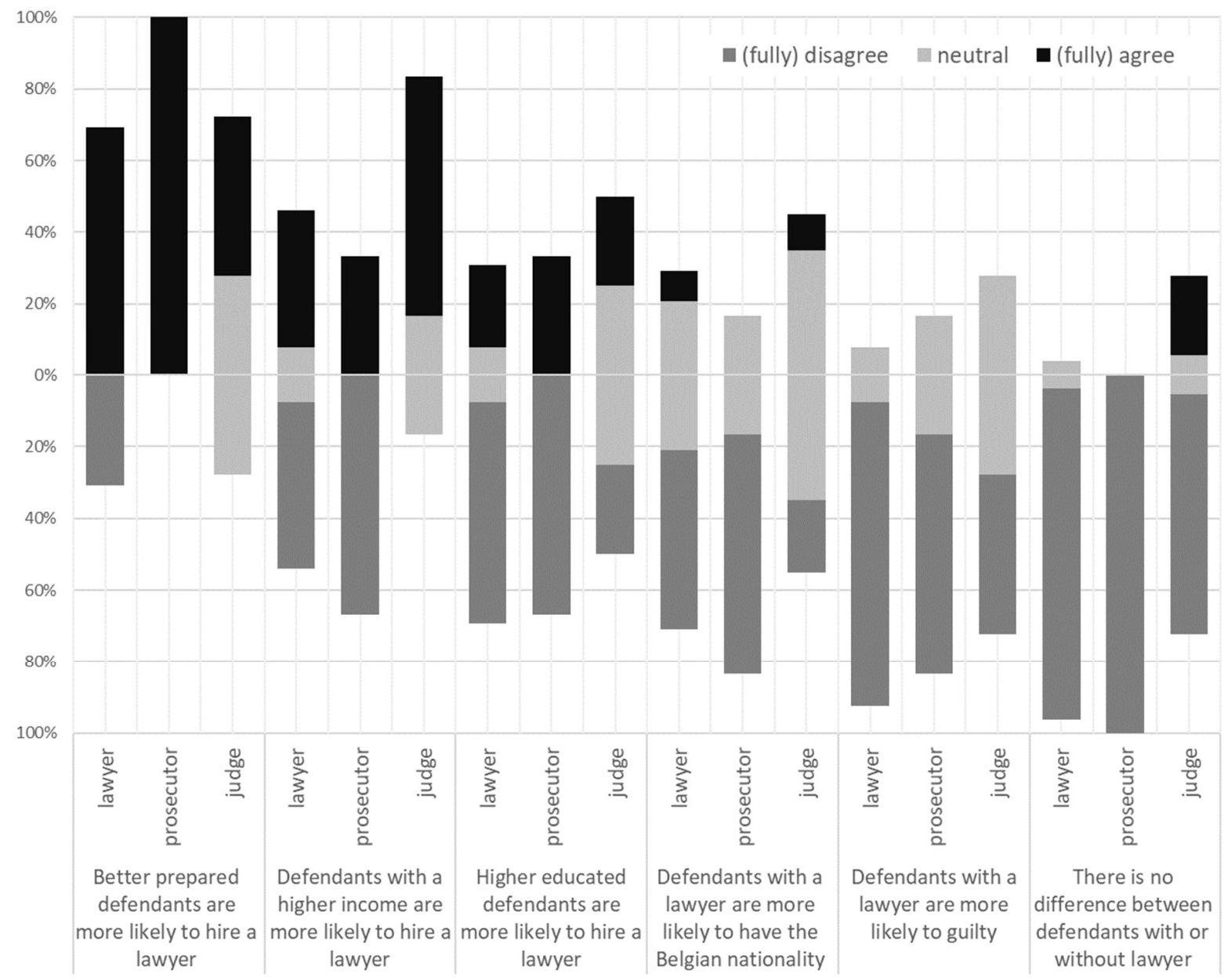


Table 1

Case Outcomes

\begin{tabular}{|c|c|c|c|c|c|c|c|}
\hline & & \multicolumn{2}{|c|}{$\begin{array}{c}\text { Full sample } \\
(\mathrm{N}=1,330)\end{array}$} & \multicolumn{2}{|c|}{$\begin{array}{l}\text { Professional Individuals } \\
(\mathrm{N}=585)\end{array}$} & \multicolumn{2}{|c|}{$\begin{array}{c}\text { Private Individuals } \\
(\mathrm{N}=745)\end{array}$} \\
\hline & & Guilty & Acquitted & Guilty & Acquitted & Guilty & Acquitted \\
\hline & & 1173 & 157 & 514 & 71 & 659 & 86 \\
\hline \multirow{2}{*}{ Fine } & $\mathrm{Y}$ & 999 & & 412 & & 587 & \\
\hline & $\mathrm{N}$ & 174 & & 102 & & 72 & \\
\hline \multirow{2}{*}{ Forfeiture of gains ${ }^{a}$} & $\mathrm{Y}$ & 43 & & 37 & & 6 & \\
\hline & $\mathrm{N}$ & 1130 & & 477 & & 653 & \\
\hline \multirow{2}{*}{$\begin{array}{l}\text { Monetary sanction } \\
\text { (fine and/or forfeiture) }\end{array}$} & $\mathrm{Y}$ & 1002 & & 414 & & 588 & \\
\hline & $\mathrm{N}$ & 171 & & 100 & & 71 & \\
\hline \multirow{2}{*}{ Prison sentence } & $\mathrm{Y}$ & 103 & & 53 & & 50 & \\
\hline & $\mathrm{N}$ & 1070 & & 461 & & 609 & \\
\hline \multirow{2}{*}{$\begin{array}{l}\text { Problem solving } \\
\text { sanction }^{\mathrm{b}}\end{array}$} & $\mathrm{Y}$ & 220 & & 91 & & 129 & \\
\hline & $\mathrm{N}$ & 953 & & 423 & & 530 & \\
\hline
\end{tabular}

"Y" indicates the imposition of a particular judicial sanction.

"N" indicates the absence of a particular judicial sanction.

${ }^{a}$ Forfeiture of gains involves the requirement for a guilty defendant to pay the government funds equal to the gains secured by violating environmental laws, i.e., forfeiture of illegally acquired benefits.

$\mathrm{b}$ Problem solving sanctions include waste removal orders, injunctions to case a business operation for safety reasons, and other remedial actions. 
Table 2

\section{Probit Estimation of Binary Outcomes - Key Results}

[p-values shown in bold where $\mathrm{p} \leq 0.10]$

Model 1: controls $=$ basic

Model 2: controls $=$ basic + culpability

Model 3: controls $=$ basic + culpability + damages

Model 4: controls $=$ basic + culpability + damages + legal adjustments

Model 5: controls $=$ basic + culpability + damages + legal adjustments + legal mechanics

Model 6: controls $=$ basic + culpability + damages + legal adjustments + legal mechanics + defendant characteristics

\begin{tabular}{|c|c|c|c|c|c|}
\hline \multirow{2}{*}{ Model } & \multicolumn{2}{|c|}{$\begin{array}{l}\text { Lawyer Presence: } \\
\text { Probit Coefficient }\end{array}$} & \multicolumn{2}{|c|}{ Estimation Summary } & \multirow{2}{*}{$\mathrm{N}$} \\
\hline & Magnitude & p-value & $\begin{array}{c}\text { Wald Test of } \\
\text { Zero Slopes: p-value }\end{array}$ & Pseudo $\mathrm{R}^{2}$ & \\
\hline \multicolumn{6}{|c|}{ Guilty Verdict $^{\mathrm{a}}$} \\
\hline 1 & -0.3153 & 0.008 & 0.000 & 0.0619 & 1,330 \\
\hline 2 & -0.3308 & 0.046 & 0.000 & 0.3417 & 1,316 \\
\hline 3 & -0.2857 & 0.049 & 0.000 & 0.3868 & 1,296 \\
\hline 4 & -0.2721 & 0.063 & 0.000 & 0.4748 & 1,296 \\
\hline 5 & -0.2336 & 0.119 & 0.000 & 0.5096 & 1,296 \\
\hline 6 & -0.2865 & 0.066 & 0.000 & 0.5090 & 1,250 \\
\hline \multicolumn{6}{|c|}{ Fine Imposition ${ }^{b}$} \\
\hline 1 & -0.4996 & 0.000 & 0.000 & 0.0834 & 1,173 \\
\hline 2 & -0.6116 & 0.000 & 0.000 & 0.1403 & 1,160 \\
\hline 3 & -0.6278 & 0.000 & 0.000 & 0.1633 & 1,140 \\
\hline 4 & -0.5753 & 0.000 & 0.000 & 0.2082 & 1,140 \\
\hline 5 & -0.5789 & 0.000 & 0.000 & 0.2106 & 1,140 \\
\hline 6 & -0.5911 & 0.000 & 0.000 & 0.2104 & 1,099 \\
\hline \multicolumn{6}{|c|}{ Monetary Sanction Imposition ${ }^{b}$} \\
\hline 1 & -0.5039 & 0.000 & 0.000 & 0.0822 & 1,173 \\
\hline 2 & -0.6197 & 0.000 & 0.000 & 0.1398 & 1,160 \\
\hline 3 & -0.6288 & 0.000 & 0.000 & 0.1629 & 1,140 \\
\hline 4 & -0.5711 & 0.000 & 0.000 & 0.2114 & 1,140 \\
\hline 5 & -0.5724 & 0.000 & 0.000 & 0.2145 & 1,140 \\
\hline 6 & -0.5894 & 0.000 & 0.000 & 0.2146 & 1,099 \\
\hline
\end{tabular}




\begin{tabular}{|c|c|c|c|c|c|}
\hline \multicolumn{7}{|c|}{ Prison Sentence $^{\mathrm{c}}$} \\
\hline 1 & -0.1626 & 0.178 & 0.014 & 0.0675 & 1,173 \\
\hline 2 & -0.3340 & $\mathbf{0 . 0 1 1}$ & 0.000 & 0.1509 & 1,160 \\
\hline 3 & -0.4303 & $\mathbf{0 . 0 0 4}$ & 0.000 & 0.2160 & 1,160 \\
\hline 4 & -0.3495 & $\mathbf{0 . 0 2 5}$ & 0.000 & 0.2747 & 1,160 \\
\hline 5 & -0.3515 & $\mathbf{0 . 0 2 3}$ & 0.000 & 0.2825 & 1,160 \\
\hline 6 & -0.3563 & $\mathbf{0 . 0 2 7}$ & 0.000 & 0.2910 & 1,119 \\
\hline
\end{tabular}

\begin{tabular}{|c|c|c|c|c|c|}
\hline \multicolumn{7}{|c|}{ Problem Solving Sanction Imposition $^{\mathrm{d}}$} \\
\hline 1 & 0.0963 & 0.394 & 0.000 & 0.1220 & 1,048 \\
\hline 2 & -0.0261 & 0.823 & 0.000 & 0.1549 & 1,036 \\
\hline 3 & -0.0946 & 0.468 & 0.000 & 0.2475 & 1,036 \\
\hline 4 & -0.0308 & 0.814 & 0.000 & 0.2661 & 1,036 \\
\hline 5 & -0.0267 & 0.841 & 0.000 & 0.2692 & 1,036 \\
\hline 6 & -0.0209 & 0.876 & 0.000 & 0.2784 & 995 \\
\hline
\end{tabular}

a The sample for Model 2 excludes 14 observations for which culpability, e.g., count of proven accusations, data are missing. The samples for Models 3, 4, 5, and 6 exclude 20 observations for which the public health damage indicator equals 1 because this value predicts success perfectly; estimation of Models 3, 4, 5, and 6 excludes this regressor. The sample for Model 6 excludes 46 observations for which defendant personal characteristics, e.g., gender, data are missing.

b The sample for Models 2, 3, 4, 5, and 6 excludes 13 observations for which culpability, e.g., count of proven accusations, data are missing. The samples for Models 3, 4, 5, and 6 exclude 20 observations for which the public health damage indicator equals 1 because this value predicts success perfectly; estimation of Models 3, 4, 5, and 6 excludes this regressor. The sample for Model 6 excludes 41 observations for which defendant personal characteristics, e.g., gender, data are missing.

c The sample for Models 2, 3, 4, 5, and 6 excludes 13 observations for which culpability, e.g., count of proven accusations, data are missing. The sample for Model 6 excludes 41 observations for which defendant personal characteristics, e.g., gender, data are missing.

d The sample for Models 1 through 6 exclude 125 observations for which the Brugge court indicator equals 1 because this value predicts failure perfectly; estimation of Models 1 through 6 excludes this regressor. The sample for Models 2, 3, 4, 5, and 6 additionally excludes 12 observations for which culpability, e.g., count of proven accusations, data are missing. The sample for Model 6 excludes 41 observations for which defendant personal characteristics, e.g., gender, data are missing. 
Table 3

Tobit Estimation of Bottom-Censored Outcomes - Key Results

[p-values shown in bold where $\mathrm{p} \leq 0.10$ ]

Model 1: controls $=$ basic

Model 2: controls $=$ basic + culpability

Model 3: controls $=$ basic + culpability + damages

Model 4: controls $=$ basic + culpability + damages + legal adjustments

Model 5: controls $=$ basic + culpability + damages + legal adjustments + legal mechanics

Model 6: controls $=$ basic + culpability + damages + legal adjustments + legal mechanics + defendant characteristics

\begin{tabular}{|c|c|c|c|c|c|c|}
\hline \multirow[b]{2}{*}{ Model } & \multicolumn{2}{|c|}{ Lawyer Presence: Coefficient } & \multicolumn{2}{|c|}{ Estimation Summary } & \multirow[b]{2}{*}{$\mathrm{N}^{\mathrm{a}}$} & \multirow{2}{*}{$\begin{array}{l}\text { Bottom } \\
\text { Censored } \\
\text { at Zero: } \\
\text { \# of Obs }\end{array}$} \\
\hline & Magnitu & $\mathrm{p}-$ & $\begin{array}{c}\text { F Test of } \\
\text { Zero Slopes: p-value }\end{array}$ & Pseudo $\mathrm{R}^{2}$ & & \\
\hline
\end{tabular}

Fine: Effective Magnitude ${ }^{b}$

\begin{tabular}{|l|c|c|c|c|c|c|}
\hline 1 & -781.72 & 0.222 & 0.004 & 0.0024 & 1,171 & 287 \\
\hline 2 & $-2,797.15$ & $\mathbf{0 . 0 1 7}$ & 0.001 & 0.0087 & 1,158 & 285 \\
\hline 3 & $-2,921.61$ & $\mathbf{0 . 0 0 4}$ & 0.006 & 0.0104 & 1,158 & 285 \\
\hline 4 & $-2,282.23$ & $\mathbf{0 . 0 1 2}$ & 0.000 & 0.0114 & 1,158 & 285 \\
\hline 5 & $-2,533.99$ & $\mathbf{0 . 0 1 2}$ & 0.001 & 0.0119 & 1,158 & 285 \\
\hline 6 & $-2,863.00$ & $\mathbf{0 . 0 1 2}$ & 0.003 & 0.0123 & 1,117 & 281 \\
\hline
\end{tabular}

Fine: Suspended Magnitude

\begin{tabular}{|l|l|l|l|l|l|l|}
\hline 1 & $5,315.72$ & $\mathbf{0 . 0 1 1}$ & 0.860 & 0.0101 & 1,173 & 776 \\
\hline 2 & $3,616.57$ & $\mathbf{0 . 0 1 0}$ & 0.916 & 0.0154 & 1,160 & 770 \\
\hline 3 & $4,337.58$ & $\mathbf{0 . 0 0 8}$ & 0.966 & 0.0187 & 1,160 & 770 \\
\hline 4 & $4,011.39$ & $\mathbf{0 . 0 1 2}$ & 0.946 & 0.0196 & 1,160 & 770 \\
\hline 5 & $3,858.75$ & $\mathbf{0 . 0 1 2}$ & 0.982 & 0.0203 & 1,160 & 770 \\
\hline 6 & $2,993.46$ & $\mathbf{0 . 0 3 3}$ & 0.988 & 0.0209 & 1,119 & 738 \\
\hline
\end{tabular}

Monetary Sanction: Effective Magnitude ${ }^{b}$

\begin{tabular}{|l|l|l|l|l|l|l|}
\hline 1 & -486.65 & 0.593 & 0.005 & 0.0028 & 1,171 & 281 \\
\hline 2 & $-3,006.42$ & $\mathbf{0 . 0 1 2}$ & 0.000 & 0.0100 & 1,158 & 279 \\
\hline 3 & $-2,930.81$ & $\mathbf{0 . 0 0 7}$ & 0.014 & 0.0128 & 1,158 & 279 \\
\hline 4 & $-2,053.56$ & $\mathbf{0 . 0 4 5}$ & 0.001 & 0.0140 & 1,158 & 279 \\
\hline 5 & $-2,446.17$ & $\mathbf{0 . 0 2 4}$ & 0.002 & 0.0148 & 1,158 & 279 \\
\hline 6 & $-2,694.97$ & $\mathbf{0 . 0 2 5}$ & 0.006 & 0.0152 & 1,117 & 275 \\
\hline
\end{tabular}




\begin{tabular}{|c|c|c|c|c|c|c|}
\hline \multicolumn{7}{|c|}{ Monetary Sanction: Suspended Magnitude ${ }^{\mathrm{b}}$} \\
\hline 1 & $5,321.90$ & $\mathbf{0 . 0 1 1}$ & 0.862 & 0.0101 & 1,171 & 774 \\
\hline 2 & $3,606.64$ & $\mathbf{0 . 0 1 0}$ & 0.917 & 0.0155 & 1,158 & 768 \\
\hline 3 & $4,306.27$ & $\mathbf{0 . 0 0 8}$ & 0.964 & 0.0189 & 1,158 & 768 \\
\hline 4 & $3,988.51$ & $\mathbf{0 . 0 1 2}$ & 0.943 & 0.0198 & 1,158 & 768 \\
\hline 5 & $3,840.75$ & $\mathbf{0 . 0 1 2}$ & 0.980 & 0.0206 & 1,158 & 768 \\
\hline 6 & $2,965.35$ & $\mathbf{0 . 0 3 4}$ & 0.988 & 0.0211 & 1,117 & 734 \\
\hline
\end{tabular}

\begin{tabular}{|l|l|c|c|c|c|c|}
\hline \multicolumn{7}{|c|}{ Prison Term: Effective Magnitude } \\
\hline 1 & -5.503 & $\mathbf{0 . 0 0 5}$ & 0.001 & 0.0781 & 1,173 & 1,137 \\
\hline 2 & -7.310 & $\mathbf{0 . 0 0 0}$ & 0.000 & 0.1355 & 1,160 & 1,125 \\
\hline 3 & -7.624 & $\mathbf{0 . 0 0 0}$ & 0.000 & 0.1873 & 1,160 & 1,125 \\
\hline 4 & -6.084 & $\mathbf{0 . 0 0 1}$ & 0.000 & 0.2355 & 1,160 & 1,125 \\
\hline 5 & -6.043 & $\mathbf{0 . 0 0 1}$ & 0.000 & 0.2729 & 1,160 & 1,125 \\
\hline 6 & -6.677 & $\mathbf{0 . 0 0 0}$ & 0.000 & 0.2796 & 1,119 & 1,084 \\
\hline \multicolumn{7}{|c|}{ Prison Term: Suspended Magnitude } \\
\hline 1 & 0.878 & 0.387 & 0.170 & 0.0492 & 1,173 & 1,103 \\
\hline 2 & -0.414 & 0.658 & 0.000 & 0.1070 & 1,160 & 1,091 \\
\hline 3 & -0.651 & 0.489 & 0.000 & 0.1420 & 1,160 & 1,091 \\
\hline 4 & -0.341 & 0.717 & 0.000 & 0.1678 & 1,160 & 1,091 \\
\hline 5 & -0.452 & 0.620 & 0.000 & 0.1707 & 1,160 & 1,091 \\
\hline 6 & -0.427 & 0.655 & 0.000 & 0.1772 & 1,119 & 1,051 \\
\hline
\end{tabular}

a The sample for Models 2, 3, 4, 5, and 6 excludes 13 observations for which culpability, e.g., count of proven accusations, data are missing. The sample for Model 6 additionally excludes 41 observations for which defendant personal characteristics, e.g., gender, data are missing.

b The sample for estimation of fine magnitudes and monetary sanction magnitudes excludes 2 observations for which fine magnitude data are missing. 
Table 4

Judges' Perceived Impacts of Legal Representation on Court Decisions: Survey Respondents' Assessment of whether Factors are Important

\begin{tabular}{|c|c|c|c|c|}
\hline & $\begin{array}{l}\text { Certainly } \\
\text { Yes }\end{array}$ & Maybe & $\begin{array}{l}\text { Certainly } \\
\text { No }\end{array}$ & $\begin{array}{l}\text { Not Able } \\
\text { to Assess }\end{array}$ \\
\hline Better understanding of procedure & 23 & 2 & 0 & 0 \\
\hline Better understanding of case content & 20 & 5 & 0 & 0 \\
\hline $\begin{array}{l}\text { Lawyer speaks the language of the prosecutor, judge, } \\
\text { fining official... }\end{array}$ & 17 & 5 & 1 & 1 \\
\hline Case is presented in a more structured way & 13 & 8 & 2 & 2 \\
\hline $\begin{array}{l}\text { It's a signal that the defendant takes the case } \\
\text { seriously }\end{array}$ & 8 & 9 & 5 & 3 \\
\hline Lower probability of prison sentence & 5 & 15 & 3 & 2 \\
\hline Less serious sanctions & 4 & 17 & 2 & 2 \\
\hline Higher probability of settlement & 4 & 14 & 3 & 3 \\
\hline Higher probability of acquittal & 2 & 18 & 3 & 2 \\
\hline Lower expected fine & 2 & 17 & 4 & 2 \\
\hline Case is finalized more quickly & 1 & 8 & 11 & 5 \\
\hline Higher probability of dismissal & 1 & 7 & 9 & 7 \\
\hline
\end{tabular}




\section{Appendix Table A-1}

\section{Probit Estimation of Binary Outcomes - Full Results for Model 6}

Model 6: controls $=$ basic + culpability + damages + legal adjustments + legal mechanics + defendant characteristics

Appendix Table A-1.a. Guilty Verdict, Fine Imposition, and Monetary Sanction Imposition

\begin{tabular}{|c|c|c|c|c|c|c|}
\hline \multirow[t]{2}{*}{ Regressor } & \multicolumn{2}{|c|}{ Guilty Verdict } & \multicolumn{2}{|c|}{$\begin{array}{c}\text { Fine } \\
\text { Imposition }\end{array}$} & \multicolumn{2}{|c|}{$\begin{array}{l}\text { Monetary } \\
\text { Sanction }\end{array}$} \\
\hline & Coeff & p-val & Coeff & $\mathrm{p}$-val & Coeff & p-val \\
\hline Lawyer Present $(0,1)^{\mathrm{a}}$ & -0.2866 & 0.066 & $\mid-0.5911$ & 0.000 & -0.5894 & 0.000 \\
\hline Professional Defendant $(0,1)^{b}$ & -1.1521 & 0.000 & -0.6335 & 0.002 & -0.6209 & 0.003 \\
\hline Year $2004(0,1)^{\mathrm{c}}$ & 0.1669 & 0.405 & -0.2740 & 0.119 & -0.2443 & 0.163 \\
\hline Year $2005(0,1)^{\mathrm{c}}$ & 0.2581 & 0.175 & -0.2530 & 0.140 & -0.2171 & 0.205 \\
\hline Year $2006(0,1)^{\mathrm{c}}$ & 0.3524 & 0.118 & -0.3364 & 0.054 & -0.2737 & 0.117 \\
\hline Quarter 2 $(0,1)^{\mathrm{d}}$ & -0.1381 & 0.491 & 0.0333 & 0.832 & -0.0066 & 0.966 \\
\hline Quarter 3 $(0,1)^{\mathrm{d}}$ & -0.2511 & 0.306 & 0.1323 & 0.494 & 0.1004 & 0.604 \\
\hline Quarter 4 $(0,1)^{\mathrm{d}}$ & 0.3155 & 0.100 & 0.0045 & 0.976 & -0.0207 & 0.889 \\
\hline Brugge Court $(0,1)^{\mathrm{e}}$ & -0.1097 & 0.690 & -0.1417 & 0.540 & -0.1813 & 0.434 \\
\hline Ieper or Veurne Courts $(0,1$ & -0.4411 & 0.049 & -0.1190 & 0.568 & -0.0601 & 0.776 \\
\hline Oudenaarde Court $(0,1)^{\mathrm{e}}$ & 0.0108 & 0.976 & 0.0196 & 0.929 & 0.0026 & 0.991 \\
\hline Kortrijk Court $(0,1)^{\mathrm{e}}$ & 0.9128 & 0.014 & 0.3209 & 0.201 & 0.3084 & 0.220 \\
\hline Dendermonde Court $(0,1)^{\mathrm{e}}$ & 0.0529 & 0.788 & 0.3655 & 0.017 & 0.3587 & 0.020 \\
\hline Agricultural Sector $(0,1)^{\mathrm{f}}$ & 0.9519 & 0.003 & 0.6213 & 0.013 & 0.6288 & 0.013 \\
\hline Manufacturing or Electricity Sectors $(0,1)^{\mathrm{f}}$ & 1.7095 & 0.000 & 0.7398 & 0.010 & 0.7433 & 0.010 \\
\hline Construction Sector $(0,1)^{f}$ & 0.9502 & 0.026 & 0.1419 & 0.634 & 0.1389 & 0.645 \\
\hline Trade Sector $(0,1)^{\mathrm{f}}$ & 1.5696 & 0.000 & 0.5014 & 0.065 & 0.5441 & 0.048 \\
\hline Accommodation or Food Sectors $(0,1)^{f}$ & 2.0573 & 0.000 & 1.0552 & 0.000 & 1.0444 & 0.000 \\
\hline Proven Accusations (count) & 1.3866 & 0.000 & 0.1426 & 0.074 & 0.1592 & 0.052 \\
\hline Average Length of Offense Time per Ac & -0.0002 & 0.208 & 0.0000 & 0.757 & 0.0000 & 0.831 \\
\hline Offense Done for Gain $(0,1)^{g}$ & 1.9977 & 0.008 & 0.9792 & 0.001 & 0.9573 & 0.002 \\
\hline Offense Done Willingly with Purp & 0.0379 & 0.912 & -0.0776 & 0.706 & -0.0621 & 0.767 \\
\hline Civil Party Presence at Verdict Level $(0,1)^{\mathrm{i}}$ & 0.1651 & 0.462 & -0.0339 & 0.851 & -0.0621 & 0.732 \\
\hline Damage: Individual Health $(0,1)^{j}$ & 1.2103 & 0.007 & 0.3454 & 0.463 & 0.3360 & 0.475 \\
\hline Damage: Public Health $(0,1)^{j}$ & $\mathrm{n} / \mathrm{a}$ & $\mathrm{n} / \mathrm{a}$ & $\mathrm{n} / \mathrm{a}$ & $\mathrm{n} / \mathrm{a}$ & $\mathrm{n} / \mathrm{a}$ & $\mathrm{n} / \mathrm{a}$ \\
\hline Damage: Nature in General $(0,1)^{j}$ & -0.0985 & 0.829 & -0.1186 & 0.713 & -0.1554 & 0.636 \\
\hline Pollution: Waste $(0,1)^{\mathrm{k}}$ & -0.5263 & 0.041 & 0.3273 & 0.055 & 0.3073 & 0.076 \\
\hline Pollution: Soil or Groundwater $(0,1)^{\mathrm{k}}$ & -0.7672 & 0.007 & 0.1715 & 0.419 & 0.1465 & 0.497 \\
\hline Pollution: Surface Water $(0,1)^{\mathrm{k}}$ & -0.6685 & 0.022 & -0.2304 & 0.233 & -0.2164 & 0.271 \\
\hline Pollution: Noise $(0,1)^{\mathrm{k}}$ & -0.4256 & 0.224 & -0.0482 & 0.830 & -0.0541 & 0.811 \\
\hline Pollution: No Harm $(0,1)^{\mathrm{k}}$ & -0.1244 & 0.726 & -0.4759 & 0.046 & -0.5149 & 0.032 \\
\hline Legal Violation: Permit in General $(0,1$ & -0.9276 & 0.000 & 0.0527 & 0.757 & -0.0099 & 0.954 \\
\hline Previous Conviction $(0,1)^{\mathrm{m}}$ & 1.8988 & 0.000 & 0.9152 & 0.000 & 0.9503 & 0.000 \\
\hline Priority Status $(0,1)^{\mathrm{n}}$ & -0.5933 & 0.035 & 0.2963 & 0.108 & 0.3274 & 0.079 \\
\hline $\begin{array}{l}\text { Clean-up, Steps to Limit Damage, or Compliance } \\
\text { Regained }(0,1)^{\circ}\end{array}$ & 1.1847 & 0.000 & $\mid-0.2779$ & 0.044 & -0.3116 & 0.026 \\
\hline Discovery Route: Routine $(0,1)^{\mathrm{p}}$ & 0.2900 & 0.412 & -0.0929 & 0.662 & -0.0944 & 0.659 \\
\hline Discovery Route: Complaint $(0,1)^{\mathrm{p}}$ & -1.0672 & 0.000 & 0.2152 & 0.282 & 0.2030 & 0.313 \\
\hline Discovery Route: Police $(0,1)^{p}$ & -0.3982 & 0.120 & 0.1204 & 0.665 & 0.2613 & 0.371 \\
\hline Discovery Route: Other $(0,1)^{p}$ & 0.0754 & 0.812 & 0.0102 & 0.965 & 0.0629 & 0.788 \\
\hline
\end{tabular}




\begin{tabular}{|l|r|r|r|r|r|r|}
\hline Defendant Age (years) & -0.0010 & 0.855 & 0.0043 & 0.308 & 0.0051 & 0.236 \\
\hline Defendant Gender: male $(0,1)^{\mathrm{q}}$ & -0.0857 & 0.545 & 0.0002 & 0.999 & 0.0146 & 0.914 \\
\hline Defendant Citizenship: Belgian $(0,1)^{\mathrm{r}}$ & 0.3830 & 0.045 & -0.0303 & 0.900 & 0.0004 & 0.999 \\
\hline
\end{tabular}

Note: Estimation also includes an intercept term.

${ }^{\text {a }}$ Omitted category: lawyer absent.

${ }^{\mathrm{b}}$ Omitted category: private individual defendant.

${ }^{c}$ Omitted category: year of 2003.

${ }^{\mathrm{d}}$ Omitted category: quarter 1.

${ }^{\mathrm{e}}$ Omitted category: Gent Court.

${ }^{\mathrm{f}}$ Omitted category: other sectors (including water supply, transport and storage, service, arts and recreation, and unknown or missing).

${ }^{g}$ Omitted category: offense not done for gain.

${ }^{\mathrm{h}}$ Omitted category: offense not done willingly with purpose.

${ }^{\mathrm{i}}$ Omitted category: civil party absent at the verdict level.

${ }^{\mathrm{j}}$ Omitted category: absence of particular damage type.

${ }^{\mathrm{k}}$ Omitted category: absence of particular pollution type.

${ }^{1}$ Omitted category: absence of permit in general violation (which may include a waste violation, noise violation, or manure violation).

${ }^{\mathrm{m}}$ Omitted category: no previous conviction.

${ }^{\mathrm{n}}$ Omitted category: lack of priority status.

${ }^{\circ}$ Omitted category: not relevant or no information available.

${ }^{\mathrm{p}}$ Omitted category: absence of particular discovery route (which may include the case of no information about the discovery route).

${ }^{\mathrm{q}}$ Omitted category: female defendant.

${ }^{\mathrm{r}}$ Omitted category: foreigner within Belgium. 
Appendix Table A-1.b. Prison Sentence Imposition and Problem Solving Penalty Imposition

\begin{tabular}{|c|c|c|c|c|}
\hline \multirow{2}{*}{ Regressor } & \multicolumn{2}{|c|}{ Prison Sentence } & \multicolumn{2}{|c|}{$\begin{array}{c}\text { Problem Solving } \\
\text { Sanction }\end{array}$} \\
\hline & Coeff & p-value & Coeff & p-value \\
\hline Lawyer Present $(0,1)^{\mathrm{a}}$ & -0.3563 & 0.027 & -0.0209 & 0.876 \\
\hline Professional Defendant $(0,1)^{b}$ & -0.2574 & 0.249 & -0.0381 & 0.871 \\
\hline Year $2004(0,1)^{\mathrm{c}}$ & -0.1611 & 0.446 & 0.2358 & 0.250 \\
\hline Year $2005(0,1)^{\mathrm{c}}$ & -0.2245 & 0.250 & 0.3586 & 0.075 \\
\hline Year $2006(0,1)^{\mathrm{c}}$ & -0.6288 & 0.003 & 0.4582 & 0.018 \\
\hline Quarter 2 $(0,1)^{\mathrm{d}}$ & \begin{tabular}{|l|}
0.0632 \\
\end{tabular} & 0.715 & 0.1087 & 0.524 \\
\hline Quarter 3 $(0,1)^{\mathrm{d}}$ & \begin{tabular}{|l|}
0.1631 \\
\end{tabular} & 0.551 & 0.6212 & 0.010 \\
\hline Quarter 4 $(0,1)^{\mathrm{d}}$ & -0.2876 & 0.111 & 0.3227 & 0.065 \\
\hline Brugge Court $(0,1)^{\mathrm{e}}$ & \begin{tabular}{|l|}
-0.1912 \\
\end{tabular} & 0.518 & $\mathrm{n} / \mathrm{a}$ & $\mathrm{n} / \mathrm{a}$ \\
\hline Ieper or Veurne Courts $(0,1)^{\mathrm{e}}$ & \begin{tabular}{|l|}
-0.0551 \\
\end{tabular} & 0.877 & -0.7051 & 0.033 \\
\hline Oudenaarde Court $(0,1)^{\mathrm{e}}$ & \begin{tabular}{|l|}
0.2662 \\
\end{tabular} & 0.318 & 0.2335 & 0.344 \\
\hline Kortrijk Court $(0,1)^{\mathrm{e}}$ & -0.4871 & 0.248 & -0.1394 & 0.685 \\
\hline Dendermonde Court $(0,1)^{\mathrm{e}}$ & \begin{tabular}{|l|}
-0.0458 \\
\end{tabular} & 0.803 & 0.8129 & 0.000 \\
\hline Agricultural Sector $(0,1)^{\mathrm{f}}$ & 0.2058 & 0.523 & 0.4307 & 0.168 \\
\hline Manufacturing or Electricity Sectors $(0,1)^{f}$ & 0.3177 & 0.364 & 0.5168 & 0.175 \\
\hline Construction Sector $(0,1)^{f}$ & 0.1668 & 0.600 & 0.1705 & 0.600 \\
\hline Trade Sector $(0,1)^{\mathrm{f}}$ & -0.2781 & 0.464 & 0.2904 & 0.288 \\
\hline Accommodation or Food Sectors $(0,1)^{f}$ & 0.6965 & 0.084 & 0.5178 & 0.158 \\
\hline Proven Accusations (count) & \begin{tabular}{|l|}
0.1242 \\
\end{tabular} & 0.099 & -0.0623 & 0.331 \\
\hline Average Length of Offense Time per Accusation (days) & 0.0001 & 0.449 & 0.0003 & 0.008 \\
\hline Offense Done for Gain $(0,1)^{\mathrm{g}}$ & 0.3347 & 0.084 & 0.3178 & 0.092 \\
\hline Offense Done Willingly with Purpose $(0,1)^{\mathrm{h}}$ & \begin{tabular}{|l|}
0.1672 \\
\end{tabular} & 0.420 & -0.0156 & 0.936 \\
\hline Civil Party Presence at Verdict Level $(0,1)^{\mathrm{i}}$ & 0.2499 & 0.221 & 0.3752 & 0.041 \\
\hline Damage: Individual Health $(0,1)^{\mathrm{j}}$ & 0.3605 & 0.285 & 0.9426 & 0.005 \\
\hline Damage: Public Health $(0,1)^{j}$ & 0.9340 & 0.055 & -1.2929 & 0.063 \\
\hline Damage: Nature in General $(0,1)^{j}$ & 0.1833 & 0.542 & 0.2254 & 0.455 \\
\hline Pollution: Waste $(0,1)^{\mathrm{k}}$ & 0.3075 & 0.133 & 1.0241 & 0.000 \\
\hline Pollution: Soil or Groundwater $(0,1)^{\mathrm{k}}$ & -0.1225 & 0.603 & 0.1686 & 0.517 \\
\hline Pollution: Surface Water $(0,1)^{\mathrm{k}}$ & 0.0907 & 0.715 & -0.4872 & 0.109 \\
\hline Pollution: Noise $(0,1)^{\mathrm{k}}$ & -0.2309 & 0.569 & -0.9190 & 0.008 \\
\hline Pollution: No Harm $(0,1)^{\mathrm{k}}$ & \begin{tabular}{|l|}
-0.3580 \\
\end{tabular} & 0.319 & -0.7227 & 0.074 \\
\hline Legal Violation: Permit in General $(0,1)^{1}$ & 0.2827 & 0.174 & 0.7574 & 0.000 \\
\hline Previous Conviction $(0,1)^{\mathrm{m}}$ & 0.5245 & 0.000 & 0.1181 & 0.375 \\
\hline Priority Status $(0,1)^{\mathrm{n}}$ & \begin{tabular}{|l|}
0.6969 \\
\end{tabular} & 0.000 & -0.0586 & 0.736 \\
\hline Clean-up, Steps to Limit Damage, Compliance Regained $(0,1)^{\circ}$ & -0.5013 & 0.023 & -0.6447 & 0.000 \\
\hline Discovery Route: Routine $(0,1)^{\mathrm{p}}$ & 0.1693 & 0.488 & -0.0610 & 0.802 \\
\hline Discovery Route: Complaint $(0,1)^{\mathrm{p}}$ & 0.0543 & 0.797 & 0.0080 & 0.965 \\
\hline Discovery Route: Police $(0,1)^{p}$ & -0.2487 & 0.307 & 0.3686 & 0.128 \\
\hline Discovery Route: Other $(0,1)^{\mathrm{p}}$ & 0.4884 & 0.020 & 0.0429 & 0.874 \\
\hline Defendant Age (years) & \begin{tabular}{|l|}
-0.0089 \\
\end{tabular} & 0.057 & 0.0005 & 0.904 \\
\hline Defendant Gender: male $(0,1)^{\mathrm{q}}$ & -0.0872 & 0.611 & -0.1313 & 0.282 \\
\hline Defendant Citizenship: Belgian $(0,1)^{\mathrm{r}}$ & 0.1266 & 0.540 & 0.3407 & 0.059 \\
\hline
\end{tabular}


Note: Estimation also includes an intercept term.

${ }^{\text {a }}$ Omitted category: lawyer absent.

${ }^{\mathrm{b}}$ Omitted category: private individual defendant.

${ }^{\mathrm{c}}$ Omitted category: year of 2003.

${ }^{\mathrm{d}}$ Omitted category: quarter 1.

${ }^{\mathrm{e}}$ Omitted category: Gent Court.

${ }^{\mathrm{f}}$ Omitted category: other sectors (including water supply, transport and storage, service, arts and recreation, and unknown or missing).

${ }^{g}$ Omitted category: offense not done for gain.

${ }^{\mathrm{h}}$ Omitted category: offense not done willingly with purpose.

${ }^{\mathrm{i}}$ Omitted category: civil party absent at the verdict level.

${ }^{\mathrm{j}}$ Omitted category: absence of particular damage type.

${ }^{\mathrm{k}}$ Omitted category: absence of particular pollution type.

${ }^{1}$ Omitted category: absence of permit in general violation (which may include a waste violation, noise violation, or manure violation).

${ }^{\mathrm{m}}$ Omitted category: no previous conviction.

${ }^{\mathrm{n}}$ Omitted category: lack of priority status.

${ }^{\circ}$ Omitted category: not relevant or no information available.

${ }^{\mathrm{p}}$ Omitted category: absence of particular discovery route (which may include the case of no information about the discovery route).

${ }^{\mathrm{q}}$ Omitted category: female defendant.

${ }^{\mathrm{r}}$ Omitted category: foreigner within Belgium. 


\section{Appendix Table A-2}

Tobit Estimation of Bottom-Censored Outcomes - Full Results for Model 6

Model 6: controls $=$ basic + culpability + damages + legal adjustments + legal mechanics + defendant characteristics

Appendix Table A-2.a. Fine Magnitudes: Effective and Suspended

\begin{tabular}{|c|c|c|c|c|}
\hline \multirow{2}{*}{ Regressor } & \multicolumn{2}{|c|}{ Fine: Effective } & \multicolumn{2}{|c|}{ Fine: Suspended } \\
\hline & Coeff & p-val & Coeff & $\mathrm{p}$-val \\
\hline Lawyer Present $(0,1)^{\mathrm{a}}$ & $-2,863.00$ & 0.012 & $2,993.46$ & 0.033 \\
\hline Professional Defendant $(0,1)^{b}$ & $-5,743.32$ & 0.045 & $-2,364.90$ & 0.358 \\
\hline Year $2004(0,1)^{\mathrm{c}}$ & $-1,743.08$ & 0.130 & $-1,505.60$ & 0.405 \\
\hline Year $2005(0,1)^{\mathrm{c}}$ & $1,298.43$ & 0.437 & $1,483.75$ & 0.427 \\
\hline Year $2006(0,1)^{\mathrm{c}}$ & $-2,342.18$ & 0.053 & $-2,193.04$ & 0.232 \\
\hline Quarter 2 $(0,1)^{d}$ & -377.82 & 0.835 & -875.89 & 0.672 \\
\hline Quarter 3 $(0,1)^{d}$ & -724.89 & 0.636 & -76.17 & 0.970 \\
\hline Quarter $4(0,1)^{d}$ & 126.78 & 0.923 & 77.31 & 0.958 \\
\hline Brugge Court $(0,1)^{\mathrm{e}}$ & $-5,417.54$ & 0.018 & $-4,893.93$ & 0.106 \\
\hline Ieper or Veurne Courts $(0,1)^{\mathrm{e}}$ & -678.03 & 0.633 & $-5,024.32$ & 0.075 \\
\hline Oudenaarde Court $(0,1)^{\mathrm{e}}$ & 72.43 & 0.968 & $-6,997.26$ & 0.016 \\
\hline Kortrijk Court $(0,1)^{\mathrm{e}}$ & $2,342.84$ & 0.355 & $4,460.69$ & 0.187 \\
\hline Dendermonde Court $(0,1)^{\mathrm{e}}$ & $2,607.42$ & 0.194 & $3,063.71$ & 0.167 \\
\hline Agricultural Sector $(0,1)^{\mathrm{f}}$ & $8,441.09$ & 0.115 & $14,533.35$ & 0.029 \\
\hline Manufacturing or Electricity Sectors $(0,1)^{f}$ & $1,870.85$ & 0.410 & $6,713.59$ & 0.044 \\
\hline Construction Sector $(0,1)^{\mathrm{f}}$ & $2,584.34$ & 0.475 & $2,060.08$ & 0.454 \\
\hline Trade Sector $(0,1)^{f}$ & $3,488.32$ & 0.160 & $2,468.89$ & 0.416 \\
\hline Accommodation or Food Sectors $(0,1)^{f}$ & $5,588.36$ & 0.122 & $8,837.68$ & 0.064 \\
\hline Proven Accusations (count) & $2,222.65$ & 0.095 & $2,183.44$ & 0.110 \\
\hline Average Length of Offense Time per & 0.82 & 0.301 & 2.03 & 0.079 \\
\hline Offense Done for Gain $(0,1)^{\mathrm{g}}$ & $8,519.86$ & 0.002 & $3,391.98$ & 0.114 \\
\hline Offense Done Willingly with Purpos & $3,699.64$ & 0.220 & $6,535.24$ & 0.065 \\
\hline Civil Party Presence at Verdict Level $(0,1)^{\mathrm{i}}$ & $2,608.81$ & 0.272 & -329.72 & 0.900 \\
\hline Damage: Individual Health $(0,1)^{\mathrm{j}}$ & $-1,268.00$ & 0.737 & $-3,551.19$ & 0.353 \\
\hline Damage: Public Health $(0,1)^{j}$ & $-2,819.97$ & 0.277 & $2,176.18$ & 0.648 \\
\hline Damage: Nature in General $(0,1)^{j}$ & $2,716.54$ & 0.506 & $-3,516.02$ & 0.322 \\
\hline Pollution: Waste $(0,1)^{\mathrm{k}}$ & $6,522.52$ & 0.075 & $5,898.85$ & 0.071 \\
\hline Pollution: Soil or Groundwater $(0,1)^{\mathrm{k}}$ & $4,662.49$ & 0.222 & $7,272.93$ & 0.068 \\
\hline Pollution: Surface Water $(0,1)^{\mathrm{k}}$ & $5,087.40$ & 0.112 & $1,576.20$ & 0.604 \\
\hline Pollution: Noise $(0,1)^{\mathrm{k}}$ & $5,514.78$ & 0.078 & 838.43 & 0.778 \\
\hline Pollution: No Harm $(0,1)^{\mathrm{k}}$ & 728.20 & 0.919 & $-1,560.43$ & 0.770 \\
\hline Legal Violation: Permit in General $(0,1)^{1}$ & $2,852.90$ & 0.144 & $-3,811.02$ & 0.064 \\
\hline Previous Conviction $(0,1)^{\mathrm{m}}$ & $3,131.16$ & 0.014 & $-2,906.85$ & 0.130 \\
\hline Priority Status $(0,1)^{\mathrm{n}}$ & $1,701.70$ & 0.221 & $2,646.18$ & 0.170 \\
\hline Clean-up, Steps to Limit Damage, Compliance Regained $(0,1)^{\circ}$ & $-4,900.00$ & 0.025 & $2,243.92$ & 0.107 \\
\hline Discovery Route: Routine $(0,1)^{\mathrm{p}}$ & $1,654.29$ & 0.636 & $2,047.99$ & 0.521 \\
\hline Discovery Route: Complaint $(0,1)^{\mathrm{p}}$ & $4,165.57$ & 0.147 & $2,141.68$ & 0.453 \\
\hline Discovery Route: Police $(0,1)^{\mathrm{p}}$ & 196.19 & 0.959 & $3,097.16$ & 0.395 \\
\hline Discovery Route: Other $(0,1)^{p}$ & $-2,871.98$ & 0.226 & $-3,755.76$ & 0.204 \\
\hline
\end{tabular}




\begin{tabular}{|l|r|r|r|r|}
\hline Defendant Age (years) & 70.78 & 0.086 & 81.98 & 0.118 \\
\hline Defendant Gender: male $(0,1)^{\mathrm{q}}$ & $1,063.42$ & 0.229 & $-2,326.49$ & 0.109 \\
\hline${\text { Defendant Citizenship: Belgian }(0,1)^{\mathrm{r}}}^{\text {r }}$ & -502.74 & 0.622 & $3,682.15$ & 0.098 \\
\hline
\end{tabular}

Note: Estimation also includes an intercept term.

${ }^{a}$ Omitted category: lawyer absent.

${ }^{\mathrm{b}}$ Omitted category: private individual defendant.

${ }^{c}$ Omitted category: year of 2003.

${ }^{\mathrm{d}}$ Omitted category: quarter 1.

e Omitted category: Gent Court.

${ }^{\mathrm{f}}$ Omitted category: other sectors (including water supply, transport and storage, service, arts and recreation, and unknown or missing).

${ }^{g}$ Omitted category: offense not done for gain.

${ }^{\mathrm{h}}$ Omitted category: offense not done willingly with purpose.

${ }^{\mathrm{i}}$ Omitted category: civil party absent at the verdict level.

${ }^{\mathrm{j}}$ Omitted category: absence of particular damage type.

${ }^{\mathrm{k}}$ Omitted category: absence of particular pollution type.

${ }^{1}$ Omitted category: absence of permit in general violation (which may include a waste violation, noise violation, or manure violation).

${ }^{\mathrm{m}}$ Omitted category: no previous conviction.

${ }^{\mathrm{n}}$ Omitted category: lack of priority status.

${ }^{\circ}$ Omitted category: not relevant or no information available.

${ }^{\mathrm{p}}$ Omitted category: absence of particular discovery route (which may include the case of no information about the discovery route).

${ }^{\mathrm{q}}$ Omitted category: female defendant.

${ }^{\mathrm{r}}$ Omitted category: foreigner within Belgium. 
Appendix Table A-2.b. Monetary Sanction Magnitudes: Effective and Suspended

\begin{tabular}{|c|c|c|c|c|}
\hline \multirow[t]{2}{*}{ Regressor } & \multicolumn{2}{|c|}{$\begin{array}{l}\text { Monetary } \\
\text { Sanction: } \\
\text { Effective }\end{array}$} & \multicolumn{2}{|c|}{$\begin{array}{l}\text { Monetary } \\
\text { Sanction: } \\
\text { Suspended }\end{array}$} \\
\hline & Coeff & p-val & Coeff & p-val \\
\hline Lawyer Present $(0,1)^{a}$ & $-2,694.97$ & 0.025 & $2,965.35$ & 0.034 \\
\hline Professional Defendant $(0,1)^{b}$ & $-9,056.23$ & 0.038 & $-2,561.41$ & 0.329 \\
\hline Year $2004(0,1)^{\mathrm{c}}$ & $-4,328.29$ & 0.090 & $-1,478.89$ & 0.413 \\
\hline Year $2005(0,1)^{\mathrm{c}}$ & $-1,182.30$ & 0.687 & $1,441.63$ & 0.438 \\
\hline Year $2006(0,1)^{\mathrm{c}}$ & $-5,553.32$ & 0.079 & $-2,015.16$ & 0.259 \\
\hline Quarter 2 $(0,1)^{\mathrm{d}}$ & $1,127.95$ & 0.622 & $-1,066.21$ & 0.612 \\
\hline Quarter 3 $(0,1)^{\mathrm{d}}$ & 452.51 & 0.840 & -201.70 & 0.920 \\
\hline Quarter 4 $(0,1)^{\mathrm{d}}$ & -104.91 & 0.943 & -78.85 & 0.958 \\
\hline Brugge Court $(0,1)^{e}$ & $-10,134.09$ & 0.005 & $-4,867.40$ & 0.107 \\
\hline Ieper or Veurne Courts $(0,1)^{\mathrm{e}}$ & -74.69 & 0.969 & $-5,078.59$ & 0.075 \\
\hline Oudenaarde Court $(0,1)^{\mathrm{e}}$ & $-1,872.89$ & 0.417 & $-6,957.20$ & 0.017 \\
\hline Kortrijk Court $(0,1)^{\mathrm{e}}$ & $1,798.30$ & 0.525 & $4,498.57$ & 0.184 \\
\hline Dendermonde Court $(0,1)^{\mathrm{e}}$ & $2,743.46$ & 0.218 & $3,270.78$ & 0.151 \\
\hline Agricultural Sector $(0,1)^{\mathrm{f}}$ & $11,114.47$ & 0.053 & $14,545.94$ & 0.028 \\
\hline Manufacturing or Electricity Sectors $(0,1)^{\mathrm{f}}$ & $14,842.10$ & 0.141 & $6,588.47$ & 0.046 \\
\hline Construction Sector $(0,1)^{\mathrm{f}}$ & $4,215.17$ & 0.331 & $2,059.59$ & 0.452 \\
\hline Trade Sector $(0,1)^{\mathrm{f}}$ & $6,647.92$ & 0.090 & $2,446.76$ & 0.421 \\
\hline Accommodation or Food Sectors $(0,1)^{\mathrm{f}}$ & $9,942.88$ & 0.053 & $8,929.78$ & 0.063 \\
\hline Proven Accusations (count) & $4,643.45$ & 0.056 & $2,095.70$ & 0.114 \\
\hline Average Length of Offense Tim & 2.23 & 0.142 & 2.02 & 0.079 \\
\hline Offense Done for Gain $(0,1)^{\mathrm{g}}$ & $7,710.57$ & 0.008 & $3,730.91$ & 0.092 \\
\hline Offense Done Willingly with Purpose $(0,1)^{\mathrm{h}}$ & $1,326.67$ & 0.727 & $6,744.50$ & 0.061 \\
\hline Civil Party Presence at Verdict Level $(0,1)^{\mathrm{i}}$ & $6,440.92$ & 0.110 & -507.94 & 0.845 \\
\hline Damage: Individual Health $(0,1)^{j}$ & $-1,467.14$ & 0.703 & $-3,408.64$ & 0.369 \\
\hline Damage: Public Health $(0,1)^{j}$ & $-3,827.82$ & 0.243 & $2,184.45$ & 0.645 \\
\hline Damage: Nature in General $(0,1)^{j}$ & $4,018.07$ & 0.332 & $-3,611.26$ & 0.313 \\
\hline Pollution: Waste $(0,1)^{\mathrm{k}}$ & $9,499.85$ & 0.021 & $5,989.84$ & 0.068 \\
\hline Pollution: Soil or Groundwater $(0,1)^{\mathrm{k}}$ & $4,873.07$ & 0.292 & $7,870.21$ & 0.059 \\
\hline Pollution: Surface Water $(0,1)^{\mathrm{k}}$ & $10,757.70$ & 0.033 & $2,277.94$ & 0.476 \\
\hline Pollution: Noise $(0,1)^{\mathrm{k}}$ & $6,169.10$ & 0.075 & 906.16 & 0.761 \\
\hline Pollution: No Harm $(0,1)^{\mathrm{k}}$ & $-2,054.04$ & 0.786 & $-1,513.14$ & 0.775 \\
\hline Legal Violation: Permit in General $(0,1)^{1}$ & $1,080.77$ & 0.675 & $-3,508.41$ & 0.074 \\
\hline Previous Conviction $(0,1)^{\mathrm{m}}$ & $4,209.59$ & 0.002 & $-2,903.51$ & 0.131 \\
\hline Priority Status $(0,1)^{\mathrm{n}}$ & 451.45 & 0.845 & $2,368.99$ & 0.207 \\
\hline Clean-up, Steps to Limit Damage, Compliance Regained $(0,1)^{\circ}$ & $-7,829.24$ & 0.005 & $2,183.25$ & 0.116 \\
\hline Discovery Route: Routine $(0,1)^{\mathrm{p}}$ & $7,476.15$ & 0.141 & $1,907.01$ & 0.544 \\
\hline Discovery Route: Complaint $(0,1)^{\mathrm{p}}$ & $4,316.47$ & 0.146 & $2,135.79$ & 0.453 \\
\hline Discovery Route: Police $(0,1)^{\mathrm{p}}$ & 408.66 & 0.914 & $3,498.27$ & 0.346 \\
\hline Discovery Route: Other $(0,1)^{\mathrm{p}}$ & $-1,658.42$ & 0.521 & $-3,823.32$ & 0.198 \\
\hline Defendant Age (years) & 73.66 & 0.099 & 78.89 & 0.124 \\
\hline Defendant Gender: male $(0,1)^{\mathrm{q}}$ & $2,053.59$ & 0.155 & $-2,446.56$ & 0.097 \\
\hline Defendant Citizenship: Belgian $(0,1)^{\mathrm{r}}$ & -527.35 & 0.678 & $3,773.59$ & 0.093 \\
\hline
\end{tabular}


Note: Estimation also includes an intercept term.

${ }^{\text {a }}$ Omitted category: lawyer absent.

${ }^{\mathrm{b}}$ Omitted category: private individual defendant.

${ }^{\mathrm{c}}$ Omitted category: year of 2003.

${ }^{\mathrm{d}}$ Omitted category: quarter 1.

${ }^{\mathrm{e}}$ Omitted category: Gent Court.

${ }^{\mathrm{f}}$ Omitted category: other sectors (including water supply, transport and storage, service, arts and recreation, and unknown or missing).

${ }^{g}$ Omitted category: offense not done for gain.

${ }^{\mathrm{h}}$ Omitted category: offense not done willingly with purpose.

${ }^{\mathrm{i}}$ Omitted category: civil party absent at the verdict level.

${ }^{\mathrm{j}}$ Omitted category: absence of particular damage type.

${ }^{\mathrm{k}}$ Omitted category: absence of particular pollution type.

${ }^{1}$ Omitted category: absence of permit in general violation (which may include a waste violation, noise violation, or manure violation).

${ }^{\mathrm{m}}$ Omitted category: no previous conviction.

${ }^{\mathrm{n}}$ Omitted category: lack of priority status.

${ }^{\circ}$ Omitted category: not relevant or no information available.

${ }^{\mathrm{p}}$ Omitted category: absence of particular discovery route (which may include the case of no information about the discovery route).

${ }^{\mathrm{q}}$ Omitted category: female defendant.

${ }^{\mathrm{r}}$ Omitted category: foreigner within Belgium. 
Appendix Table A-2.c. Prison Terms: Effective and Suspended

\begin{tabular}{|c|c|c|c|c|}
\hline \multirow[t]{2}{*}{ Regressor } & \multicolumn{2}{|c|}{$\begin{array}{l}\text { Prison Term: } \\
\text { Effective }\end{array}$} & \multicolumn{2}{|c|}{$\begin{array}{l}\text { Prison Term: } \\
\text { Suspended }\end{array}$} \\
\hline & Coeff & $\mathrm{p}$-value & Coeff & $p$-value \\
\hline Lawyer Present $(0,1)^{a}$ & -6.677 & 0.000 & -0.427 & 0.655 \\
\hline Professional Defendant $(0,1)^{b}$ & -4.108 & 0.072 & -2.453 & 0.090 \\
\hline Year $2004(0,1)^{\mathrm{c}}$ & -5.862 & 0.007 & 0.255 & 0.839 \\
\hline Year $2005(0,1)^{c}$ & -1.914 & 0.330 & -0.875 & 0.441 \\
\hline Year $2006(0,1)^{\mathrm{c}}$ & -4.469 & 0.052 & -3.341 & 0.009 \\
\hline Quarter 2 $(0,1)^{\mathrm{d}}$ & -0.984 & 0.616 & 0.398 & 0.706 \\
\hline Quarter $3(0,1)^{d}$ & 3.244 & 0.227 & -1.322 & 0.464 \\
\hline Quarter $4(0,1)^{d}$ & -2.257 & 0.242 & -1.502 & 0.195 \\
\hline Brugge Court $(0,1)^{\mathrm{e}}$ & -4.335 & 0.091 & -0.242 & 0.909 \\
\hline Ieper or Veurne Courts $(0,1)^{\mathrm{e}}$ & -2.282 & 0.564 & 0.789 & 0.748 \\
\hline Oudenaarde Court $(0,1)^{\mathrm{e}}$ & -3.949 & 0.240 & 2.565 & 0.115 \\
\hline Kortrijk Court $(0,1)^{\mathrm{e}}$ & -39.883 & & -0.957 & 0.710 \\
\hline Dendermonde Court $(0,1)^{\mathrm{e}}$ & -2.716 & 0.124 & 0.913 & 0.438 \\
\hline Agricultural Sector $(0,1)^{\mathrm{f}}$ & -2.393 & 0.456 & 3.876 & 0.037 \\
\hline Manufacturing or Electricity Sectors $(0,1)^{\mathrm{f}}$ & -46.846 & & 4.266 & 0.038 \\
\hline Construction Sector $(0,1)^{\mathrm{f}}$ & 2.481 & 0.409 & 1.940 & 0.304 \\
\hline Trade Sector $(0,1)^{\mathrm{f}}$ & 2.884 & 0.244 & -1.738 & 0.556 \\
\hline Accommodation or Food Sectors $(0,1)^{f}$ & -0.870 & 0.842 & 5.072 & 0.018 \\
\hline Proven Accusations (count) & 0.245 & 0.689 & 0.903 & 0.032 \\
\hline Average Length of Offense Time per Accusation (days) & -0.003 & 0.037 & 0.001 & 0.113 \\
\hline Offense Done for Gain $(0,1)^{\mathrm{g}}$ & 2.773 & 0.171 & 1.862 & 0.154 \\
\hline Offense Done Willingly with Purpose $(0,1)^{\mathrm{h}}$ & 2.655 & 0.081 & 0.593 & 0.633 \\
\hline Civil Party Presence at Verdict Level $(0,1)^{\mathrm{i}}$ & 2.866 & 0.104 & 1.536 & 0.199 \\
\hline Damage: Individual Health $(0,1)^{\mathrm{j}}$ & 0.339 & 0.916 & 0.552 & 0.759 \\
\hline Damage: Public Health $(0,1)^{j}$ & -1.181 & 0.777 & 4.653 & 0.042 \\
\hline Damage: Nature in General $(0,1)^{j}$ & 6.712 & 0.010 & -0.413 & 0.821 \\
\hline Pollution: Waste $(0,1)^{\mathrm{k}}$ & 5.719 & 0.069 & 1.747 & 0.148 \\
\hline Pollution: Soil or Groundwater $(0,1)^{\mathrm{k}}$ & 3.764 & 0.157 & -1.159 & 0.388 \\
\hline Pollution: Surface Water $(0,1)^{\mathrm{k}}$ & -2.252 & 0.388 & 2.023 & 0.159 \\
\hline Pollution: Noise $(0,1)^{\mathrm{k}}$ & 4.234 & 0.353 & -0.521 & 0.810 \\
\hline Pollution: No Harm $(0,1)^{\mathrm{k}}$ & -4.591 & 0.235 & -0.535 & 0.803 \\
\hline Legal Violation: Permit in General $(0,1)^{1}$ & 4.805 & 0.036 & 0.941 & 0.440 \\
\hline Previous Conviction $(0,1)^{\mathrm{m}}$ & 5.561 & 0.000 & 1.529 & 0.103 \\
\hline Priority Status $(0,1)^{\mathrm{n}}$ & 4.487 & 0.006 & 3.998 & 0.000 \\
\hline Clean-up, Steps to Limit Damage, Compliance Regained $(0,1)^{\circ}$ & -3.570 & 0.113 & -2.456 & 0.069 \\
\hline Discovery Route: Routine $(0,1)^{\mathrm{p}}$ & 6.651 & 0.000 & 0.903 & 0.563 \\
\hline Discovery Route: Complaint $(0,1)^{\mathrm{p}}$ & -6.014 & 0.011 & 2.064 & 0.069 \\
\hline Discovery Route: Police $(0,1)^{\mathrm{p}}$ & -1.939 & 0.325 & -1.083 & 0.517 \\
\hline Discovery Route: Other $(0,1)^{p}$ & 5.708 & 0.002 & 0.471 & 0.771 \\
\hline Defendant Age (years) & 0.071 & 0.107 & -0.062 & 0.057 \\
\hline Defendant Gender: male $(0,1)^{\mathrm{q}}$ & 3.015 & 0.277 & -1.262 & 0.205 \\
\hline Defendant Citizenship: Belgian $(0,1)^{\mathrm{r}}$ & 2.005 & 0.348 & 1.087 & 0.465 \\
\hline
\end{tabular}


Note: Estimation also includes an intercept term.

${ }^{\text {a }}$ Omitted category: lawyer absent.

${ }^{\mathrm{b}}$ Omitted category: private individual defendant.

${ }^{\mathrm{c}}$ Omitted category: year of 2003.

${ }^{\mathrm{d}}$ Omitted category: quarter 1.

${ }^{\mathrm{e}}$ Omitted category: Gent Court.

${ }^{\mathrm{f}}$ Omitted category: other sectors (including water supply, transport and storage, service, arts and recreation, and unknown or missing).

${ }^{g}$ Omitted category: offense not done for gain.

${ }^{\mathrm{h}}$ Omitted category: offense not done willingly with purpose.

${ }^{\mathrm{i}}$ Omitted category: civil party absent at the verdict level.

${ }^{\mathrm{j}}$ Omitted category: absence of particular damage type.

${ }^{\mathrm{k}}$ Omitted category: absence of particular pollution type.

${ }^{1}$ Omitted category: absence of permit in general violation (which may include a waste violation, noise violation, or manure violation).

${ }^{\mathrm{m}}$ Omitted category: no previous conviction.

${ }^{\mathrm{n}}$ Omitted category: lack of priority status.

${ }^{\circ}$ Omitted category: not relevant or no information available.

${ }^{\mathrm{p}}$ Omitted category: absence of particular discovery route (which may include the case of no information about the discovery route).

${ }^{\mathrm{q}}$ Omitted category: female defendant.

${ }^{\mathrm{r}}$ Omitted category: foreigner within Belgium. 